\title{
Returning to First Principles of Privilege Law: Focusing on the Facts in Internal Corporate Investigations
}

\author{
Christopher T. Hines ${ }^{*}$
}

Facts are stubborn things; and whatever may be our wishes, our inclinations, or the dictates of our passions, they cannot alter the state of facts and evidence. ${ }^{1}$

-John Adams, Argument in Defense of the British Soldiers in the Boston Massacre Trials, December 4, 1770. ${ }^{2}$

\section{INTRODUCTION}

What a difference a decade makes. At the turn of the last century, the general mood in public discourse and perceptions was, in large part, optimistic. Although there were concerns regarding the Y2K problem and an attempted millennial bombing by international terrorists, ${ }^{3}$ the United States and the world maintained a fairly positive outlook on the future. Technology stocks were doing well-the NASDAQ would reach its all-time high in March 2000. ${ }^{4}$ President Clinton was serving his last years in office, and the future debates regarding the 2000 election cycle were still in the offing. However, the facts, what John Adams once

Assistant Professor of Law, Northern Illinois University College of Law. J.D. 2002, Columbia Law School; B.A. 1998, Yale University. Many thanks to Dean Jennifer L. Rosato and Professors Mark W. Cordes, Marc D. Falkoff, Daniel S. Reynolds, Laurel A. Rigertas, Lorraine A. Schmall, and Daniel M. Schneider of the Northern Illinois University College of Law, Professor Geoffrey C. Rapp of the University of Toledo College of Law, and Professor Eric A. Zacks of the Wayne State University Law School for their comments and advice. Additionally, my thanks to John R. Austin and Therese A. Clarke Arado for generous library and research support, and Brett D. Kolditz, Priti Nemani, Daniel J. Gawronski and Lauren M. Swintek for their research assistance. A summer research grant from the Northern Illinois University College of Law supported this project.

1. John Adams, No. 64. Rex v. Wemms, in 3 Legal Papers of John AdAms 98, 269 (L. Kinvin Wroth \& Hiller B. Zobel eds., 1965).

2. See id.

3. See Vernon Loeb, Planned Jan. 2000 Attacks Failed or Were Thwarted, WASH. Post, Dec. 24, 2000, at A02; Andy Serwer, The Decade From Hell ... and How the Next One Can Be Better, TIME, Dec. 7, 2009, at 30, 31 (discussing the "dreaded [Y2K] meltdown [that] never happened").

4. See Serwer, supra note 3, at 32. 
dubbed those "stubborn things," what one might have envisioned on the eve of the new millennium.

Now, things are different. After two U.S.-led wars and two economic bubbles of historic magnitude, there is a general sense of fatigue with the course of recent events as well as the vicissitudes of fortune in the globalized economy. ${ }^{6}$ In the world of high finance, the landscape has fundamentally changed. The days of the independent Wall Street investment bank, born out of a form created by law in the midst of the Great Depression - the last period of economic turmoil in U.S. history on such a scale-are now over. ${ }^{7}$ Of the five "bulge bracket" investment banks that existed prior to the financial crisis of 2008, only two-Goldman Sachs and Morgan Stanley-remain independent business enterprises. ${ }^{8}$

First to fold was Bear Stearns, which became subject to a classic bank run $^{9}$ in March 2008 when investors lost confidence in its portfolio

5. See supra note 1 and accompanying text. As David McCullough recounts in his biography of John Adams, after Adams made this statement as part of his closing argument, "[t]he jury remained out two and a half hours. Of the eight soldiers, six were acquitted and two found guilty of manslaughter, for which they were branded on their thumbs.... Years later, reflecting from the perspective of old age, [Adams] himself would call [Rex v. Wemms] the most exhaustive case he ever undertook ....” DAVID MCCUllough, JoHn ADAMs 68 (2001).

6. A 2009 Time cover featured a crying baby donning a party hat and surrounded by confetti, providing an apt depiction of this mood. See Serwer, supra note 3; see also Cover Photo: Shooting the 'Decade from Hell', TIME, http://www.time.com/time/video/player/0,32068,52630343001_ 1943210,00.html (last visited Aug. 22, 2011) ("We can assure you no babies were harmed during the creation of this week's Time magazine cover; but all was not quiet on the set.”).

7. See Andrew Ross Sorkin \& Vikas Bajaj, Shift for Goldman and Morgan Marks the End of an Era, N.Y. TIMES, Sept. 22, 2008, at A1 ("Goldman Sachs and Morgan Stanley, the last big independent investment banks on Wall Street, will transform themselves into bank holding companies subject to far greater regulation, ... a move that fundamentally reshapes an era of high finance that defined the modern Gilded Age.”). This said, the fact that economic booms will, in due time, be followed by what then seem to be inevitable busts, and that fortunes will be made only to then be subsequently lost, is nothing new in the American experience. As Tocqueville wrote in one of his many moments of insight:

The Americans dwell in a land of wonders in which everything is in a constant state of motion and every movement seems a step forward. The concept of newness is, therefore, intimately bound up in their minds with that of improvement. . . .

This universal activity which prevails in the United States, these frequent reversals of fortune, these unforeseen shifts of public and private wealth, all combine to entrench in men's minds a kind of feverish agitation, which predisposes them to make every possible effort and keeps them, so to speak, above the common level of humanity. For Americans, their whole lives are spent as if in a game of chance, in a time of revolution or a day of battle.

Alexis de Tocqueville, Democracy in America 475 (Gerald E. Bevan trans., Penguin Books 2003) (1835).

8. See Sorkin \& Bajaj, supra note 7.

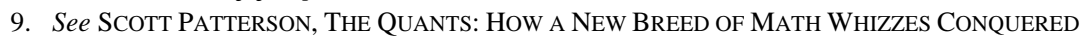


of collateralized debt obligations (CDOs) ${ }^{10}$ as a result of the onset of the subprime-mortgage crisis. After a hurried sale to JPMorgan Chase, however, things seemed fine. ${ }^{11}$ In a deal that would later prove quite controversial, the Federal Reserve Bank of New York arranged \$30 billion in special financing for Bear Stearns. ${ }^{12}$ JPMorgan Chase would assume the first $\$ 1$ billion of any losses associated with the assets of Bear Stearns, and the Federal Reserve would fund the remaining \$29 billion on a non-recourse basis to JPMorgan Chase. ${ }^{13}$ At the time, some investors felt that a widening financial crisis had been averted and that the Federal Reserve took the necessary actions to avoid the spread of contagion from the subprime-mortgage market to the financial markets as a whole. ${ }^{14}$ Indeed, among many observers in practice and the press, there was the sense that the Federal Reserve orchestrated a settlement that echoed the actions taken during the last moment of crisis on Wall

WALl StREET AND NEARLy Destroyed It 253 (2010) (discussing Bear Stearns’s clients “bolt[ing] for the exit" with billions in hand). Granted, this run on the bank had a significant modern twist in that the panic to withdraw funds from Bear Stearns, which resembles in nature the famous scene at the Bailey Building and Loan Association in It's a Wonderful Life, now occurred with much greater speed through electronic trading that, in a phrase, constituted a "global margin call." See id. at 239; IT's A WONDERFUL LIFE (Liberty Films 1946); see also Graham Bowley, The New Speed of Money, Reshaping Markets, N.Y. TIMES, Jan. 2, 2011, at BU1.

10. A collateralized debt obligation can be generally defined as an "investment-grade bond backed by a pool of variously rated bonds, including junk bonds.” BARRON's DICTIONARY OF FINANCE AND INVESTMENT TERMS 121 (John Downes \& Jordan Elliot Goodman eds., 7th ed. 2006).

11. See PATTERSON, supra note 9, at 253-54. As we now know, however, CDOs frequently received an investment-grade or AAA rating from the rating agencies, which overlooked these securities' more speculative nature. See Michael Lewis, THE Big SHORT: INSIDE THE DoOMSDAY MACHINE 206-09 (2010) (discussing Morgan Stanley and rating agencies' assessment of CDOs' risk). The role the rating agencies played in the recent financial crisis is an issue that is outside the scope of this Article. This said, Michael Lewis may have gained a revealing, if somewhat discomforting, insight in his recent reporting. As recounted by Lewis, at a Las Vegas trade convention in January 2007, Steve Eisman - a noted hedge fund manager and one of the few investors who correctly called the market—met with representatives from the rating agencies and recalled,

I remember sitting there thinking, Jeez, this is really pathetic. You know when you're with someone who is intellectually powerful: You just know it. When you sit down with Richard Posner[,] . . . you know it's Richard Posner. When you sit down with the rating agencies you know it's the rating agencies.

Id. at 157 (internal quotation marks omitted) (quoting Steve Eisman).

12. See Press Release, JPMorgan Chase \& Co., JPMorgan Chase and Bear Stearns Announce Amended Merger Agreement and Agreement for JPMorgan Chase to Purchase 39.5\% of Bear Stearns (May 24, 2008), http://investor.shareholder.com/jpmorganchase/releasedetail.cfm?Release ID $=301224$

13. Id.

14. See, e.g., Peter A. McKay, Dow Jumps 187.32 as Clouds Lift a Bit, WALl ST. J., Mar. 25, 2008, at C1 ("Investing pros said the rally in large part reflected investors' growing confidence that the Federal Reserve and other market overseers are acting effectively to address the credit crisis.”). 
Street in 1998-the almost \$4 billion bailout of Long-Term Capital Management, a leading hedge fund that engaged in complex arbitrage transactions. ${ }^{15}$

Any such confidence, however, was short-lived. Things would get much worse, and much sooner than most could envision. ${ }^{16}$ Throughout the summer of 2008, confidence in the capital markets remained uneven as market watchers continued to ponder whether the proverbial "other shoe" might drop. ${ }^{17}$ As the Federal Reserve continued to provide new facilities to increase liquidity in the credit markets, ${ }^{18}$ the question of subprime-mortgage-debt exposure continued to cast a pall over the capital markets.

Although some market watchers called the turn in the market earlier than others, ${ }^{19}$ it was not until September 15, 2008 that the air finally

15. See, e.g., Neil Irwin \& Tomoeh Murakami Tse, Fed Comes to Rescue as Wall St. Giant Slips, WASH. Post, Mar. 15, 2008, at A01 (analogizing the Federal Reserve's approach to Bear Stearns's collapse to that of the Federal Reserve Bank of New York's assistance of Long-Term Capital Management). The definitive treatment of the crisis involving Long-Term Capital Management, which includes a compelling narrative of the characters involved, remains Roger Lowenstein's When Genius Failed. See Roger Lowenstein, When GeniUs Failed: The RISE AND FALL OF LONG-TERM CAPITAL MANAGEMENT (2000).

If one looks at the Long-Term episode in isolation, one would tend to agree that the

Fed was right to intervene, just as, if confronted with a suddenly mentally unstable patient, most doctors would willingly prescribe a tranquilizer. The risks of a breakdown are immediate; those of addiction are long term. But the Long-Term Capital case must be seen for what it is: not an isolated instance but the latest in a series in which an agency of the government (or the IMF) has come to the rescue of private speculators. Id. at 230 .

16. As in every crisis in history, however, there were a number of observers who were ahead of the curve, in a manner of speaking. See, e.g., Nouriel Roubini \& BRAD SETSER, BAILOUTS OR BAIL-INS? RESPONDING TO FINANCIAL CRISES IN EMERGING ECONOMIES 377 (2004) ("Predicting future crises can be a fool's errand. But it is not a stretch to say that the IMF is likely to be forced to confront more crises of domestic confidence.”); ROBERT J. SHILLER, IRRATIONAL EXUBERANCE, at xiv (2d ed. 2009) ("Underlying all the disruptions that we are facing is an aspect of human nature that is not consistent with our ideal of rational man.”); NASSIM NiCHOLAS TALEB, THE BLACK SWAN: THE IMPACT OF THE Highly IMPROBABLE, at xvii (2007) ("One single observation can invalidate a general statement derived from millennia of confirmatory sightings of millions of white swans. All you need is one single (and, I am told, quite ugly) black bird.”); Frontline: The Warning (PBS television broadcast Oct. 20, 2009), available at http://www.pbs.org/wgbh/pages/frontline/ warning/ ("We didn't truly know the dangers in the [derivatives] market because it was a dark market. There was no transparency." (quoting Brooksley Born, former chairperson of the Commodity Futures Trading Commission)).

17. See, e.g., Tom Petruno, Will It Get Worse?, L.A. TIMES, July 6, 2008, at C1 ("Stock markets worldwide in the second quarter tried to shake off the deep gloom that gripped them in the first three months of the year. They succeeded-for a while.”).

18. See, e.g., Sudeep Reddy, Fed Extends Lending Programs as Threats Persist, WALL ST. J., July 31, 2008, at A3.

19. See sources cited supra note 16 . 
came out of the greatest financial bubble in history. ${ }^{20}$ On this date, Lehman Brothers announced its intention to file a petition under Chapter 11 of the U.S. Bankruptcy Code in the Southern District of New York. ${ }^{21}$ Shortly thereafter, the news of Lehman's bankruptcy unleashed the Furies on global capital markets. ${ }^{22}$ In a moment, credit- the lifeblood of modern financial markets-stopped flowing. ${ }^{23}$ What happened? How did a bubble in the subprime-mortgage markets infect the overall health of the economy and take down long-standing financial institutions that weathered the bleak days of the past economic downturns, including the darkest moments of the Great Depression? Why did the commercial paper markets suddenly freeze up and even blue chip companies with solid, longstanding credit ratings have no access to the credit markets? Who was in charge? What would happen next?

As we now know, a credit bubble of historic proportions, which initially formed in the housing markets through excessive subprime lending, eventually infected the overall financial markets through a complex web of transactions linking financial institutions both in the United States and abroad. ${ }^{24}$ Specifically, these transactions involved the purchase and sale of CDOs and associated hedging instruments-in essence, insurance policies-on these CDOs in the form of a security

20. As a matter of taxonomy, scholars in law, economics, and related disciplines have used different terms to define the recent financial crisis and the resulting economic downturn. For instance, Carmen Reinhart and Kenneth Rogoff define the entire economic crisis as the "Second Great Contraction" in reference to the influential work of Milton Friedman and Anna Jacobson Schwartz in A Monetary History of the United States. See CARMEn M. ReInHART \& Kenneth S. Rogoff, This Time is DiffEREnT: EIGHT CENTURIES OF FINANCIAL FOLLY, at xlv, 393 n.7 (2009) ("Contraction provides an apt description of the wholesale collapse of credit markets and asset prices that has marked the depth of these traumatic events, along with, of course, contracting employment and output.”); MILTON FRIEDMAN \& ANNA JACOBSON SCHWARTZ, A MONETARY HistORY OF THE UNITED STATES 1867-1960, at 299 (1963). For purposes of this Article, however, I adopt the more commonly used phrase of "financial crisis."

21. Press Release, Lehman Bros. Holdings Inc., Lehman Brothers Holdings Inc. Announces It Intends to File Chapter 11 Bankruptcy Petition; No Other Lehman Brothers' U.S. Subsidiaries or Affiliates, Including Its Broker-Dealer and Investment Management Subsidiaries, Are Included in the Filing (Sept. 15, 2008), available at http://www.lehman.com/press/pdf_2008/091508_lbhi_ chapter11_announce.pdf.

22. See Susanne Craig, Jefferson McCracken, Jon Hilsenrath \& Deborah Soloman, AIG, Lehman Shock Hits World Markets, WALL ST. J., Sept. 16, 2008, at A1.

23. See Tom Petruno \& Walter Hamilton, It's a Really Bad Sign When Even Banks Can't Secure a Loan, L.A. TIMES, Sept. 27, 2008, at A1.

24. See Martin Fackler, Financial Crisis Spreads to Emerging Nations, N.Y. TIMES, Oct. 24, 2008, at B1 (discussing the effect of the financial crisis on South Korea); Morning Edition: Financial Turmoil Deepening in Europe (NPR radio broadcast Oct. 6, 2008), available at http://www.npr.org/templates/story/story.php?storyId=95420466 (discussing actions by European governments to respond to the spreading financial crisis). 
known as a credit-default swap (CDS). ${ }^{25}$ Once the news of Lehman's bankruptcy became public, bank failures cascaded in rapid succession. ${ }^{26}$

Bank of America agreed to purchase all outstanding stock of Merrill Lynch in a transaction valued at approximately $\$ 50$ billion. ${ }^{27}$ Shortly thereafter, the Federal Reserve approved the conversion of both Goldman Sachs and Morgan Stanley into bank holding companies, bringing to an end the era of the independent securities firm. ${ }^{28}$ Washington Mutual, at the time the largest savings-and-loan association, went into government receivership in what would become the largest bank failure in U.S. history. ${ }^{29}$ Wachovia, then the fourth largest bank holding company in the United States, considered a takeover proposal from Citigroup, but later decided on its sale to Wells Fargo for approximately $\$ 15$ billion. $^{30}$ In concert with this fundamental reordering of the economic landscape, the federal unemployment rate peaked at $10.1 \%$ in October $2009 .{ }^{31}$

We have witnessed and continue to experience what many consider to be the worst economic downturn since the Great Depression. In such circumstances, it is necessary and appropriate to ask some fundamental questions on the economic laws and regulations that, for better or worse, played a contributing role in the financial crisis. Although the ongoing financial-reform efforts have already yielded significant changes in applicable financial regulation, ${ }^{32}$ a further discussion regarding the

25. See Simon Johnson \& JAmes KWAK, 13 BAnKers: The WALl STREet TAKeOver And THE NEXT FinANCIAL MELTDOWN 81 (2010). ("A credit default swap is a form of insurance on debt; the 'buyer' of the swap pays a fixed premium to the 'seller,' who agrees to pay off the debt if the debtor fails to do so. Typically the debt is a bond or a similar fixed income security, and the debtor is the issuer of the bond.”).

26. For a comprehensive list of the notable events in the financial crisis, including the financial reform efforts that are ongoing, see Financial Crisis Time Line, SULLIVAN \& WORCESTER LLP, http://www.sandw.com/news-240.html. See also FIN. CRISIS INQUIRY COMM’N, THE FINANCIAL CRISIS INQUIRY COMMISSION REPORT (2011) [hereinafter FCIC REPORT]. The Financial Crisis Inquiry Commission is a ten-member, bipartisan commission established pursuant to the Fraud Enforcement and Recovery Act of 2009. Id. at xi. Its purpose is to "examine the causes, domestic and global, of the current financial and economic crisis in the United States." Fraud Enforcement and Recovery Act, Pub. L. No. 111-21, § 5(c)(1), 123 Stat. 1617, 1626 (2009).

27. See FCIC REPORT, supra note 26, at 382-86 (discussing Bank of America's “shotgun wedding” with Merrill Lynch).

28. See Sorkin \& Bajaj, supra note 7.

29. See FCIC REPORT, supra note 26, at 365-66 (describing Washington Mutual's collapse).

30. David Enrich \& Dan Fitzpatrick, Wachovia Chooses Wells Fargo, Spurns Citi, WaLl ST. J., Oct. 4, 2008, at A1; see generally FCIC REPORT, supra note 26, at 366-71 (discussing the events surrounding the Wachovia sale).

31. Labor Force Statistics from the Current Population Survey, BUREAU OF LABOR STATISTICS, http://data.bls.gov/PDQ/servlet/SurveyOutputServlet?request_action=wh\&graph_name=LN_cpsbref 3 (last visited Aug. 22, 2011).

32. See, e.g., Dodd-Frank Wall Street Reform and Consumer Protection Act, Pub. L. No. 111- 
principles and practices that existed within the enforcement of federal securities law deserves consideration. Specifically stated, are there any improvements to current enforcement of federal securities law that would work to the benefit of the U.S. economy and to all the actors therein? ${ }^{33}$

The answer that shall be presented in this Article is, simply, "yes." In particular, I focus on what has been a longstanding debate-both in legal scholarship and the wider realm of public discourse-regarding the appropriate limits of the attorney-client privilege within the context of an internal corporate investigation, as well as waiving that privilege as a means of effectively cooperating with federal securities regulators, under the existing doctrine as set forth in Upjohn Co. v. United States. ${ }^{34}$ This two-part inquiry - into the limits of the attorney-client privilege in the first instance and the scope of waiver doctrine as notably discussed under the "selective waiver" line of cases_-will proceed in the following parts.

Part II provides an overview of the relevant historical development of the attorney-client privilege as enunciated by English and American jurists. Part III addresses the evolution of the current enforcement of securities law and its interplay with the attorney-client privilege; this discussion starts with the increasing role of attorneys as "gatekeepers" 35 as first articulated by the Securities and Exchange Commission (SEC) in

203, 124 Stat. 1376 (2010); Eric A. Zacks, Unstacking the Deck? Contract Manipulation and Credit Card Affordability, 78 U. CIN. L. REV. 1471 (2010).

33. In this Article, I focus on the enforcement of federal securities law and do not address the issues associated with financial regulation enforcement. While such issues are of great importance to the future "re-regulation" of the capital markets, in order to facilitate a discussion of the relevant issues of law, this analysis is limited to issues relating to the enforcement of federal securities law.

34. 449 U.S. 383 (1981). This Article is the first in a series that will explore the intersection of corporate law and legal ethics. See Geoffrey C. HAZARD, JR. \& ANGElo DONDI, LEgAL ETHICS: A COMPARATIVE STUDY 3 (“'Legal Ethics' includes not only ethical conventions of the legal profession but also legal regulations prescribed by the authority of the state...."). While future articles will consider other topics of interest in this area of law, as well as any other issues that may arise as financial reform begins to take effect, for the purposes of the present discussion the relevant subject matter will be the corporate attorney-client privilege as first enunciated in Upjohn and as later interpreted by the lower courts and the enforcers of the federal securities laws-namely, the Securities and Exchange Commission and the Department of Justice.

35. The influential scholarship on gatekeepers in corporate law as a method of third-party enforcement is extensive. See, e.g., JoHn C. COffee JR., GateKEePers: The Professions AND CORPORATE GOVERNANCE 2 (2006) (“[A] second and superior definition of the gatekeeper is an agent who acts as a reputational intermediary to assure investors as to the quality of the 'signal' sent by the corporate issuer. The reputational intermediary does so by lending or 'pledging' its reputational capital to the corporation, thus enabling investors or the market to rely on the corporation's own disclosures or assurances where they otherwise might not."); Reinier H. Kraakman, Gatekeepers: The Anatomy of a Third-Party Enforcement Strategy, 2 J.L. ECON. \& ORG. 53, 54 n.3 (1986) ("I restrict the term gatekeepers to third parties who can disrupt misconduct by withholding support, and the term gatekeeper liability to legal regimes that impose civil or criminal sanctions on gatekeepers who fail to withhold support.”). 
the case of Carter \& Johnson, ${ }^{36}$ and ends with the evolution of SEC and Department of Justice (DOJ) policy with respect to the enforcement of federal securities laws and the weight placed on waiver of the attorneyclient privilege by corporate defendants as part of the settlement determination. Further, Part III provides a statistical analysis of recent trends in securities-law enforcement as a means of providing additional insight into the waiver issue.

Part IV presents the argument that current legal doctrine regarding the attorney-client privilege and internal corporate investigations should be reconsidered by returning to the first principles set forth by the Supreme Court in Upjohn, which remains the foundational case for this area of law. ${ }^{37}$ Specifically, I argue for the return to the factscommunication distinction as an alternative means of determining the appropriate boundaries of the corporate attorney-client privilege. In returning to the first principles of the Court in Upjohn, I argue that focusing on the facts, or those "stubborn things" in the words of John Adams, makes possible an alternative solution to the decades-long discussion that surrounds the appropriate limits of the corporate attorney-client privilege in the context of securities-law enforcement.

\section{THE HistoricAl DEVELOPMENT OF THE ATTORNEY-CLIENT PRIVILEGE}

A good place to begin arguing for a return to first principles, as set forth by the Court in Upjohn, is at the beginning. Specifically, this Part explores the historical development of the attorney-client privilege in the following areas of analysis: (a) the notable antecedents in AngloAmerican legal history; ${ }^{38}$ (b) the modern attorney-client privilege for corporations in Upjohn; ${ }^{39}$ and (c) a synopsis of the ongoing debate concerning the selective-waiver rule. ${ }^{40}$

36. Exchange Act Release No. 34-17597, [1981] Fed. Sec. L. Rep. (CCH) ๆ 82,847 (Feb. 28, 1981); see discussion infra Part III.A.

37. For purposes of this Article, I will adopt the notion of a "first principle" as a foundational proposition that cannot be deduced from any other. See, e.g., ARISTOTLE, Metaphysics, in THE COMPLETE WORKS OF ARISTOTLE: THE REVISED OXFORD TRANSLATION 1588 (Jonathan Barnes, ed., 1984) (“[T]he same attribute cannot at the same time belong and not belong to the same subject in the same respect; we must presuppose, in face of dialectical objections, any further qualifications which might be added.”). Thus, facts are facts, and communication is communication.

38. See infra Part II.A.

39. See infra Part II.B.

40. See infra Part II.C. 


\section{A. Notable Antecedents in Anglo-American Legal History}

The earliest recorded cases on the attorney-client privilege in AngloAmerican jurisprudence that remain available to scholars, along with the subsequent historical development of the prudential rules contained in these cases, provide the necessary background to the modern incarnation of the attorney-client privilege. This historical perspective is an appropriate method of inquiry in that the antecedents of the attorneyclient privilege stretch for more than 400 years of Anglo-American legal history. ${ }^{41}$ In the words of Wigmore:

The history of [the] privilege goes back to the reign of Elizabeth I, where the privilege already appears as unquestioned. It is therefore the oldest of the privileges for confidential communications. ...

The policy of the privilege has been plainly grounded since the latter part of the 1700 s on subjective considerations. In order to promote freedom of consultation of legal advisers by clients, the apprehension of compelled disclosure by the legal advisers must be removed; hence the law must prohibit such disclosure except on the client's consent. Such is the modern theory. ${ }^{42}$

It initially appears that the history of the attorney-client privilege progresses fairly uniformly from the historical antecedents to the modern form of the doctrine where the privilege-more specifically the right to waive the privilege - now rests with the client in the first instance.

As a matter of legal history, it is significant to note that at its beginnings the attorney-client privilege did not look to the issue of the client's consent, but rather to the barrister who represented the client

41. The importance of an historical perspective to the law remains a fundamental issue of method, as noted most memorably by Justice Holmes when he observed:

The rational study of law is still to a large extent the study of history. History must be a part of the study, because without it we cannot know the precise scope of rules which it is our business to know. It is a part of the rational study, because it is the first step toward an enlightened scepticism, that is, toward a deliberate reconsideration of the worth of those rules.

O.W. Holmes, The Path of the Law, 10 HARV. L. REV. 457, 469 (1897); see also N.Y. Trust Co. v. Eisner, 256 U.S. 345, 349 (1921) (“[A] page of history is worth a volume of logic.”).

42. 8 J. Wigmore, EVidenCE in TRials AT COMMON LAW §§ 2290-91, at 542, 545 (John T. McNaughton rev. ed., 1961) (footnotes omitted). 
before the relevant tribunal. ${ }^{43}$ This was a point of consequence for Wigmore, who noted that the initial theory behind the privilege "was an objective not a subjective one-a consideration for the oath and the honor of the attorney rather than for the apprehensions of his client."44 As the doctrine developed, however, Wigmore concluded that the "new theory looked to the necessity of providing subjectively for the client's freedom of apprehension in consulting his legal adviser." ${ }^{45}$ Accordingly, as a matter of legal theory, ${ }^{46}$ the historical development of the attorneyclient privilege can be seen as a movement from the protection of the professional reputation of the barrister to the interest of maintaining in confidence the communications between the client and her attorney. ${ }^{47}$ In its general perspective on the development of doctrine, such an observation undoubtedly contains the elements of truth.

Nevertheless, as Professor Geoffrey Hazard notes in his important article on the subject, the historical development of the attorney-client privilege was anything but certain or consistent:

[T] he historical foundations of the privilege are not as firm as the tenor of Wigmore's language suggests. On the contrary, recognition of the privilege was slow and halting until after 1800. It was applied only with much hesitation, and exceptions concerning crime and wrongdoing by the client evolved simultaneously with the privilege itself. ... Taken as a whole, the historical record is not authority for a broadly

43. See id. § 2290, at 543 .

44. Id.

45. Id.

46. With respect to legal theory, and as to a possible definition of such a concept, this Article adopts a specific term in order to facilitate further discussion. On these points, Professor Randy Barnett's notion of what legal theory entails and how such a concept interplays with a possible analysis of how problems in doctrine may be subsequently resolved provides some illumination.

Theories are problem-solving devices. We assess the merits of a particular theory by its ability to solve the problems that gave rise to the need for a theory. We do not, however, assess a particular theory in a vacuum. No theory in any discipline, from physics to biology to philosophy, can be expected to solve every problem raised by the discipline. Rather, we compare contending theories to see which theory handles problems the best.

Randy E. Barnett, A Consent Theory of Contract, 86 CoLUM. L. REv. 269, 269-70 (1986).

47. The impact of such an historical perspective is a significant starting point for further discussion. See, e.g., Henry SUMNER Maine, ANCIENT LAW: ITS CONNECTION WITH THE EARLY History OF SOCIETY AND ITS RELATION TO MODERn IDEAS 173-74 (Frederick Pollock ed., John Murray 1906) (1861) ("If then we employ Status, agreeably with the usage of the best writers, to signify these personal conditions only, and avoid applying the term to such conditions as are the immediate or remote result of agreement, we may say that the movement of the progressive societies has hitherto been a movement from Status to Contract."). 
stated rule of privilege or confidence. It is, rather, an invitation for reconsideration. ${ }^{48}$

In light of this more nuanced reading of legal history, it appears that what we would now consider the modern formulation of the attorneyclient privilege is a much more recent development in doctrine. Specifically, the expansion of the attorney-client privilege began in earnest in the 1830s. In two cases heard before the Court of Chancery, Bolton v. Corporation of Liverpool ${ }^{49}$ and Greenough v. Gaskell, ${ }^{50}$ Lord Brougham expanded the scope of the attorney-client privilege. At the same time, these decisions provided the fundamental grounds in policy for such an expansion-namely, that the privilege promotes communication between the client and counsel, which furthers the interests of justice in connection with court proceedings.

\section{Bolton v. Corporation of Liverpool}

In Bolton v. Corporation of Liverpool, the plaintiffs were merchants and partners in the Corporation of Liverpool. ${ }^{51}$ The partners were also defendants to an action at law by the Corporation of Liverpool "for the recovery of certain dues levied by the corporation upon the traders of that town." 52 After commencement of this initial action, the plaintiffs separately submitted this matter to the courts of equity in a bill "filed for the purpose of obtaining a discovery from the corporation in aid of the Plaintiff's defence to the action at law."53 In particular, the plaintiffs sought to compel production of certain cases upon which defendant had sought advice from its counsel, as well as any statements made by

48. Geoffrey C. Hazard, Jr., An Historical Perspective on the Attorney-Client Privilege, 66 CALIF. L. REV. 1061, 1070 (1978).

49. (1833) 39 Eng. Rep. 614 (Ch.); 1 My. \& K. 88.

50. (1833) 39 Eng. Rep. 618 (Ch.); 1 My. \& K. 98.

51. Bolton, 39 Eng. Rep. at 615; 1 My. \& K. at 88.

52. Id. at $615 ; 1 \mathrm{My} . \& \mathrm{~K}$. at 88 .

53. Id. at $615 ; 1 \mathrm{My}$. \& K. at 88 . 
counsel in relation to such cases. ${ }^{54}$ Significantly, plaintiffs claimed that these cases concerned "the right of the corporation to receive the tolls and duties" that were claimed by defendant as being in arrears in the separate action at law. ${ }^{55}$ In reviewing the applicable precedents and the arguments made by both parties, Lord Brougham observed:

If it be said that this Court compels the disclosure of whatever a party has at any time said respecting his case; nay, even wrings his conscience to disclose his belief, the answer is, that admissions not made, or thoughts not communicated to professional advisers, are not essential to the security of men's rights in Courts of Justice. Proceedings for this purpose can be conducted in full perfection, without the party informing any one of his case except his legal advisers. But without such communication no person can safely come into a Court, either to obtain redress or to defend himself..$^{56}$

As shall be discovered when assessing the ongoing debate on the appropriate limits of the attorney-client privilege for corporations under Upjohn and its progeny, here is the fundamental argument in legal theory as to the justification for an expansive interpretation of the attorneyclient privilege.

Like the defendants in Bolton, many clients seek professional legal representation as part of an adversarial process of law. Thus, the importance of uninhibited communication between the client and her counsel becomes paramount. Further, if the client cannot communicate in confidence with her counsel, she may not be sufficiently prepared to make her case in front of the competent authority. In such cases, therefore, one cannot claim that the interests of justice will be served by a rule that will effectively disincentivize the full and open disclosure of information between clients and their counsel. In Bolton, Lord Brougham recognized such concerns by denying plaintiffs' request for

54. Id. at $615 ; 1 \mathrm{My}$. \& K. at 88 . These cases and opinions would probably have qualified as fact work product - and potentially opinion work product-under the modern rules in the United States. See FED. R. CIV. P. 26(b)(3); Hickman v. Taylor, 329 U.S. 495, 508-12 (1947). Indeed, we learn from Lord Brougham that the defendant laid the cases before its counsel "to have been prepared in contemplation of and with reference to the action and suit.”' Bolton, 39 Eng. Rep. at 617; 1 My. \& K. at 94 (quoting defendant's answer). Further, the specific communications, either oral or written, between the corporation and its counsel in relation to these matters would fall within the scope of the attorney-client privilege.

55. Bolton, 39 Eng. Rep. at $615 ; 1 \mathrm{My}$. \& K at 88.

56. Id. at $617 ; 1 \mathrm{My}$. \& K. at 94-95 (emphasis added). 
production of both the cases submitted to defendant's counsel and any related statements or opinions provided by counsel. ${ }^{57}$

\section{Greenough v. Gaskell}

Similarly, in Greenough v. Gaskell, plaintiffs brought a bill that charged defendant, a solicitor who represented a client who later became bankrupt, with fraudulently concealing his client's financial status in connection with the execution of a note. ${ }^{58}$ As part of the proceedings at the lower court, plaintiff moved to compel production by the defendant of "divers books, \&c., containing entries and memorandums, and also divers papers and letters, relative to the matters in the bill," which defendant, in his answer, admitted to having in his possession. ${ }^{59}$ Notably, the defendant claimed that "such entries and memorandums were made, and such papers and letters were written, or received by him in his capacity of confidential solicitor for [his client], for whom he had been professionally concerned for a number of years." 60

Lord Brougham denied plaintiff's request by citing his prior decision in Bolton. He further elaborated that legal theory favors a more expansive treatment of the attorney-client privilege:

To compel a party himself to answer upon oath, even as to his belief or his thoughts, is one thing; nay, to compel him to disclose what he has written or spoken to others, not being his professional advisers, is competent to the party seeking the discovery; for such communications are not necessary to the conduct of judicial business, and the defence or prosecution of men's rights by the aid of skilful persons. To force from the party himself the production of communications made by him to professional men seems inconsistent with the possibility of an ignorant man safely resorting to professional advice, and can only be justified if the authority of decided cases warrants it. ...

... [I]t is out of regard to the interests of justice, which cannot be upholden, and to the administration of justice, which cannot go on, without the aid of men skilled in jurisprudence, in the practice of the Courts, and in those matters affecting rights and obligations which form the subject of all judicial proceedings. If the privilege did not exist at

57. Id. at $618 ; 1$ My. \& K. at 97.

58. (1883) 39 Eng. Rep. 618 (Ch.) 618-19; 1 My. \& K. 98, 98.

59. Id. at $619 ; 1 \mathrm{My}$. \& K. at 99-100.

60. Id. at $619 ; 1 \mathrm{My}$. \& K. at 100. 
all, every one would be thrown upon his own legal resources; deprived of all professional assistance, a man would not venture to consult any skilful person, or would only dare to tell his counsellor half his case. ${ }^{61}$

Here, one should note that Lord Brougham makes an important distinction between the right of an opposing party to seek the discovery of information through testimony under oath and the right to compel the production of communications between a client and her counsel. As will be discussed further, this distinction provides a key factor when assessing the distinction between facts, on the one hand, and communication, on the other, under the longstanding doctrine as set forth in the Upjohn line of cases. ${ }^{62}$

In terms of the historical development of the attorney-client privilege, however, Lord Brougham's opinions in Bolton and Greenough constitute a watershed that discards the prior focus on "the oath and the

61. Id. at 620-21; 1 My. \& K. at 101-03 (emphasis added).

62. See discussion infra Part II.B.2.a. Indeed, one could argue that the facts-communication distinction is a necessary premise for Lord Brougham's reasoning in Bolton and Greenough. Given that these opinions dramatically expanded the potential scope of the attorney-client privilege to cover various instances of communications between clients and their counsel, by necessity it would seem that there must be a distinction between what remains a discoverable fact under examination and communications that fall within the protection of the privilege. As Professor Hazard notes,

Together Bolton and Greenough encompass a broad range of communications: from client to lawyer, and from lawyer to client; legal advice in a strict technical sense and business-financial assistance of the sort rendered by an office lawyer; communications between barrister and client and between solicitor and client; exchanges in contemplation of litigation and ones not occasioned by the specific prospect of imminent litigation; and communications as such and the transmission of tangible items, such as preexisting documents, from client to lawyer.

Brougham held all of these matters immune from disclosure.

Hazard, supra note 48, at 1084 . As one might expect, Lord Brougham did not achieve such a dramatic change in doctrine without distinguishing a number of cases and, in one instance, simply taking no notice of an adverse precedent. See Annesley v. Anglesea, 17 How. St. Tr. 1139, 1242 (1743) (permitting testimony of an attorney in connection with an action of ejectment); Hazard, supra note 48, at 1084 ("In particular, he handled Annesley v. Anglesea in about the only way possible, that is by not citing it at all.”). Nevertheless, such judicial "activism” was not without precedent in the English courts. See, e.g., Pillans v. Van Mierop, (1765) 97 Eng. Rep. 1035 (K.B.); 3 Burr. 1663, overruled by Rann v. Hughes, (1778) 2 Eng. Rep. 18 (H.L.); 4 Brown 27. See also Mitchinson v. Hewson, (1797) 101 Eng. Rep. 1013 (K.B.) 1014 n.(a); 7 T.R. 348, 350 n.(a) (discussing Pillans and Rann). 
honor" of the barrister. ${ }^{63}$ Indeed, as Professor Hazard observes, the opinions in Bolton and Greenough "wholly disconnect the privilege from its point of origin - the fact that in court the client could not speak for himself and therefore had to inform someone to speak for him." ${ }^{4}$ Although the precise extent of the attorney-client privilege as enunciated by Lord Brougham was not fully accepted in later court decisions, ${ }^{65}$ Bolton and Greenough justified the privilege with the more fully developed notion of the "interests of justice." 66 In this sense, the attorney-client privilege, in its previous incarnation, was dead-long live the attorney-client privilege. But how would the new doctrine apply to a newly created entity - the invisible, intangible corporation?

63. In relation to this historical change in the doctrine, and in further discussion of Wigmore's analysis of the attorney-client privilege, Professor Hazard observes that

Wigmore explained the transformation of the privilege from that of the lawyer to that of the client as a transformation of the underlying theory from "objective" to "subjective." It seems at least equally plausible to attribute the change in the "holder" of the privilege to the fact that the privilege came to extend to communications not only to barristers, who stood as members of the court, but also to attorneys, who did not.

Hazard, supra note 48, at 1071 n.39.

64. Id. at 1085.

65. For instance, the modern version of the attorney-client privilege is subject to numerous exceptions, including that the privilege does not extend to pre-existing documents, business advice, or to any other matters that are not in furtherance of obtaining legal advice. See, e.g., Fisher v. United States, 425 U.S. 391, 403-04 (1976) ("[P]re-existing documents which could have been obtained by court process from the client when he was in possession may also be obtained from the attorney by similar process following transfer by the client in order to obtain more informed legal advice.”); McCaugherty v. Siffermann, 132 F.R.D. 234, 238 (N.D. Cal. 1990) (“No privilege can attach to any communication as to which a business purpose would have served as a sufficient cause, i.e., any communication that would have been made because of a business purpose, even if there had been no perceived additional interest in securing legal advice.”); 8 WIGMORE, supra note 42, § 2292, at 554 (requiring seeking "legal advice of any kind" as an element of the attorney-client privilege).

66. In a similar manner, the development of modern contract law from its historical origins in the writ of assumpsit required, as the subsequent historical development would ultimately illustrate, an initial ruling — whether implicit or explicit — that the defense of wager of law would not lie. "The point was of the first importance: had the action of assumpsit been saddled with wager of law it could never have been developed into the general contractual remedy of the common law. But matters which seem important in retrospect do not always seem important at the time.” A.W.B. Simpson, A History of THE COMMON LAW OF CONTRACT: THE RISE OF THE ACTION OF AssumPSIT 220 (1975). Similarly, in reviewing the development of the attorney-client privilege as a matter of doctrine, this critical pivot in the underlying theory-from the barrister's professional reputation to the client's interests in justice-would be difficult to underestimate. 


\title{
B. The Modern Attorney-Client Privilege for Corporations in Upjohn Co. v. United States
}

\author{
Corporations are, in a phrase, legal fictions. ${ }^{67}$ In using such a \\ phrase, ${ }^{68}$ I intend to highlight the fact that the corporation in its modern \\ form is a distant descendent of the earliest corporate forms. ${ }^{69}$
}

67. In using the phrase "legal fictions," I refer to Maine’s influential definition of legal fictions. I employ the word "fiction" in a sense considerably wider than that in which English lawyers are accustomed to use it, and with a meaning much more extensive than that which belonged to the Roman "fictiones." ... But now I employ the expression "Legal Fiction" to signify any assumption which conceals, or affects to conceal, the fact that a rule of law has undergone alteration, its letter remaining unchanged, its operation being modified. The words, therefore, include the instances of fictions which I have cited from the English and Roman law, but they embrace much more, for I should speak both of the English Case-law and of the Roman Responsa Prudentium as resting on fictions.... The fact is in both cases that the law has been wholly changed; the fiction is that it remains what it always was. It is not difficult to understand why fictions in all their forms are particularly congenial to the infancy of society. They satisfy the desire for improvement, which is not quite wanting, at the same time that they do not offend the superstitious disrelish for change which is always present.

MAINE, supra note 47, at 30-31. This said, the corporation itself is, of course, a creature of statute that may be as narrowly defined as provided by the competent legislature. See, e.g., DEL. CODE ANN. tit. 8, § 102 (West Supp. 2011) (contents of certificate of incorporation). Accordingly, here I employ the term corporation in a more expansive sense to include not only the narrow definition as set forth in statute but also the attendant rights and obligations of such a legal form as may be determined under applicable decisional law.

68. For additional discussion in respect of Maine's lasting impact in legal theory, see DANIEL R. Coquillette, The ANGlo-American Legal Heritage: InTROductory Materials 283 (2d ed. 2004) ("The lesson, put simply, was that Maine was correct about how the law develops.... We often prefer to pretend that something has stayed the same, when it has actually changed a great deal. The English monarchy is a legal fiction. So is the idea of the Constitution of the United States is unchanging. Fictions permit useful incremental reform, when wide scale reform is too threatening.”); E. Donald Elliott, The Evolutionary Tradition in Jurisprudence, 85 CoLUM. L. REV. 38, 45 (1985) ("Some aspects of Maine's work have withstood the test of time. His insights into the role legal fictions play in facilitating changes in the law, for example, are as brilliant today as when they were written.”).

69. The earliest ancestor to the modern corporation is, one may credibly claim, the joint-stock corporation as invented by those with business interests in Amsterdam in the early seventeenth century. More specifically, the chartering of the United Dutch Chartered East India Company-the Vereenigde Nederlandsche Geoctroyeerde Oostindische Compangnie (VOC)—in 1602 and the issuance of certificates in the years shortly thereafter, constituted what can be called the first public offering in history. Niall Ferguson, The Ascent of Money: A Financial History of the WORLD 128 (2008).

[T] he scale of the enterprise was unprecedented. Subscription to the Company's capital was open to all residents of the United Provinces and the charter set no upper limit on how much might be raised. ...

... The certificates issued were not quite share certificates in the modern sense, but more like receipts; the key document in law was the VOC stock ledger, where all stockholders' names were entered at the time of purchase.

Id. $128-29$. 
Nevertheless, there remains a consistency to the corporate form precisely because it is a legal fiction. For reasons well beyond the scope of this Article, and for better or worse, it appears that the modern corporation is a fixture of law for the foreseeable future. ${ }^{70}$

\section{Considering the Corporate Form}

Before continuing with the general discussion of the historical development of attorney-client privilege as doctrine, it may be helpful to consider the corporate form in and of itself. Assuming for purposes of this discussion that the modern corporation is here to stay, the critical and indeed necessary question, when stated plainly, becomes - to what extent should the modern corporation enjoy the rights and privileges that society reserves for natural persons? An answer to this question is of increasing scholarly and public debate. Within the context of First Amendment law, should corporations have the right to make available through video-on-demand within the thirty-day period prior to a presidential campaign a documentary about one of the presidential candidates? In Citizens United v. FEC, the Court answered this question in the affirmative. ${ }^{71}$ In the words of Justice Ginsburg, however, “[a] corporation, after all, is not endowed by its creator with inalienable rights., ${ }^{, 2}$ At some point in the development of doctrine, therefore, a decision must be made as to the specific rights and privileges that will be granted to the corporation and the specific rights and privileges that will not.

Without doubt, some rights and privileges clearly fall outside the purview of the modern corporate form. Significantly, the modern

70. In respect of the modern corporation, at least within the United States, here I have in mind the general scope and extent that currently exists under the Delaware General Corporation Law. See Del. Code AnN. tit. 8 (West 2010 \& Supp. 2011). However, the critiques of the modern corporate form, most notably through the corporate social responsibility school of legal thought, remain an important area of scholarly debate and discussion. See generally THE OXFORD HANDBOOK OF CORPORATE Social Responsibility (Andrew Crane et al. eds., 2008); Cynthia A. Williams, Corporate Social Responsibility in an Era of Economic Globalization, 35 U.C. DAVIS L. REV. 705 (2002). This said, recent scholarship suggests that the limited liability company (LLC) may be superior to the corporate form in every way other than historical path dependence. See Geoffrey Christopher Rapp, Preserving LLC Veil Piercing: A Response to Bainbridge, 31 J. CORP. L. 1063, 1068-77 (2006).

71. 130 S. Ct. 876, 913 (2010); but see FCC v. AT \& T Inc., 131 S. Ct. 1177, 1179 (2011) (holding that the personal privacy exemption under the Freedom of Information Act does not extend to corporations).

72. Transcript of Oral Argument at 4, Citizens United, 130 S. Ct. 876 (No. 08-205). 
corporation does not enjoy the Fifth Amendment right against selfincrimination as determined by the Court in the 1906 case of Hale $v$. Henkel. $^{73}$ Recent scholarship by Professor Julie O'Sullivan, however, has provided new insight into the Hale case and identified the weaknesses inherent in the Court's opinion. ${ }^{74}$ With this notable caveat to the precedential value of Hale, the fact remains that, as of the present, the modern corporation cannot generally claim the right against selfincrimination under the Fifth Amendment. What then of the attorneyclient privilege? Can the testimonial privilege that first came into existence to protect the professional reputation of the barrister in England, which was then turned on its head to read in the interests of the client, now apply to that "artificial being, invisible, intangible, and existing only in the contemplation of the law" corporation?

This was the issue that, as a matter of historical development of doctrine, squarely faced the Court in Upjohn Co. v. United States. ${ }^{76}$ This is also the reason why the Court's holding in Upjohn - that indeed there is an attorney-client privilege for the corporation-is of critical importance in doctrinal development on a level that can be seen as comparable, at least in respect of the corporate form, to Lord Brougham's turnabout on legal theory in Bolton and Greenough in 1833. Simply stated, as a matter of doctrine there was the attorney-client privilege before and the attorney-client privilege after Upjohn. And the

73. 201 U.S. 43, 69-70 (1906).

The right of a person under the Fifth Amendment to refuse to incriminate himself is purely a personal privilege of the witness. It was never intended to permit him to plead the fact that some third person might be incriminated by his testimony, even though he were the agent of such person.... The question whether a corporation is a "'person'” within the meaning of this Amendment really does not arise, except perhaps where a corporation is called upon to answer a bill of discovery, since it can only be heard by oral evidence in the person of some one of its agents or employees. The Amendment is limited to a person who shall be compelled in any criminal case to be a witness against himself, and if he cannot set up the privilege of a third person, he certainly cannot set up the privilege of a corporation.

Id.

74. See Julie R. O'Sullivan, The Last Straw: The Department of Justice's Privilege Waiver Policy and the Death of Adversarial Justice in Criminal Investigations of Corporations, 57 DEPAUL L. REV. 329, 351-58 (2008).

75. Trs. of Dartmouth Coll. v. Woodward, 17 U.S. (4 Wheat.) 518, 636 (1819) (“A corporation is an artificial being, invisible, intangible, and existing only in contemplation of law. Being the mere creature of law, it possesses only those properties which the charter of its creation confers upon it, either expressly, or as incidental to its very existence.”).

76. 449 U.S. 383 (1981). 
new contours of this doctrine set forth in the Court's opinion in Upjohn have, in this sense, made the difference.

\section{Upjohn Co. v. United States}

Although the facts in Upjohn are relatively straightforward, they should be considered within the context of corporate and securities practice that then prevailed. ${ }^{77}$ As a starting point, corporations faced an inhospitable - and in many cases hostile-political environment in the late 1970s. In the aftermath of the Watergate investigations and the ensuing general distrust of government and its policies, questionable payments made by or on behalf of corporations to certain foreign interests ultimately resulted in the enactment of the Foreign Corrupt Practices Act (FCPA). ${ }^{78}$ It was within this context that the Upjohn Company, a pharmaceutical manufacturer that initially gained success through the sale of certain "friable" pills, ${ }^{79}$ found itself in the midst of an internal corporate investigation regarding certain questionable payments in connection with an ongoing investigation by the Internal Revenue Service (IRS). ${ }^{80}$

Upjohn begins with what is by now a fairly familiar fact pattern for internal corporate investigations - the corporation received notice from

77. Given my more recent entry into the practice and study of law, I readily confess a lack of personal knowledge on corporate and securities practice in the late 1970s. Accordingly, I am indebted to Phil Parker, a former Deputy General Counsel at the SEC, for his recounting of such events during my early training in practice. Any errors in the historical account contained herein, however, remain solely my own.

78. See Foreign Corrupt Practices Act of 1977, Pub. L. No. 95-213, 91 Stat. 1494 (codified as amended in scattered sections of 15 U.S.C.); RALPH H. FOLSOM, MiCHAEL WALLACE GORDON \& John A. SPANOGLE, JR., INTERNATIONAL BusinesS TrANSACTIONS § 17.2, at 505-06 (2d ed. 2001). "The FCPA is a response to real and perceived harm to U.S. foreign relations with important, developed friendly nations, and the interest of the United States to prevent U.S. persons from making payments which embarrass the United States in conducting foreign policy." FOLSOM, GORDON \& SPANOGLE, supra $\S 17.2$, at 505. "There was also a more general distrust of business during the Carter Administration. All was not attributable to the President; Senator Frank Church and others in Congress appeared to view multinational corporations as inherently evil, and the FCPA as a law necessary to govern their immoral behavior.” Id. § 17.2, at 505 n.1.

79. The founder of the company, Dr. William E. Upjohn, as a “young physician loved to tinker. One of his projects was working on a way to make pills 'friable,' or easy to dissolve. At that time, pills were hard and many went through the digestive systems before their ingredients could do any good.” Roger Kullenberg, Upjohn Made His Mark on Kalamazoo, KaLAMAZOo GAZETTE, Jan. 1, 2000, at A2. Dr. Upjohn passed away in 1932 and thus never knew of the eponymous case for which, at least among legal scholars and practitioners, he may be best remembered. Id. In 1995, the Upjohn Company merged with Pharmacia AB and ceased its existence as a stand-alone business enterprise. See id.

80. Upjohn, 449 U.S. at 387. 
its independent accountants ${ }^{81}$ that, in connection with an audit of a foreign subsidiary, "the subsidiary made payments to or for the benefit of foreign government officials in order to secure government business." 82 This notice from the accountants to management typically constitutes a triggering event for an internal corporate investigation to determine the nature and extent of any "questionable payments" that may be subject to sanction by the SEC and the DOJ. ${ }^{83}$ Of particular note at this time, the SEC initiated what became known as its "voluntary disclosure program" in order to incentivize corporations to voluntarily assess their compliance with applicable federal securities laws. ${ }^{84}$ As a means of complying with this voluntary disclosure program, Upjohn's board of directors tapped the company's general counsel “'to conduct an investigation for the purpose

81. As evidence of the development of law in this area, note that in modern practice the accounting firm would most likely send a "10A letter" to management. Section 10A of the Securities Exchange Act of 1934 requires that the accounting firm inform management of any "illegal act" discovered in the course of an audit and, if necessary, resign from the engagement or report to the SEC in the event that the company fails to take "timely and appropriate remedial actions.” 15 U.S.C. § 78j-1(b)(2)(B) (2006).

82. Upjohn, 449 U.S. at 386.

83. See Jonathan R. Tuttle \& Christopher T. Hines, First Things First: Deciding Who Should Conduct Your Internal Investigation (June 24, 2003) (on file with author) (paper presented at the American Conference Institute Symposium: Trying and Defending Securities Class Actions). See also INTERNAL CORPORATE InVESTIGATIONS 417-20 (Barry F. McNeil \& Brad D. Brian eds., 3d ed. 2007) (discussing auditor involvement in internal investigations).

84. In a revealing description of the development of the voluntary disclosure program in the 1970s, the D.C. Circuit observed that

As early as 1974 the SEC was engaged in investigating the political "slush fund" practices of some corporations. Initially the SEC staff carried out its own investigations, but as the scope of the payments problem became apparent, extending to foreign as well as domestic payments, the SEC realized that it did not have the resources to investigate each case carefully. In several 1974 enforcement actions, the SEC thus sought and obtained consent decrees in which corporate defendants agreed to appoint special committees of their boards of directors - composed entirely of directors unaffiliated with management-to carry out independent investigations of the defendants' payments practices. These investigations were to be performed by outside counsel hired for that purpose and responsible only to the special committee. The results of the investigation would be embodied in a report to the special committee, which would also be shared with the SEC staff.

As the benefits of this method of investigation became apparent, the SEC began to encourage corporations to come forward voluntarily and perform the same type of independent investigation that the consent decrees had required. This effort to induce corporate self-investigation became known as the voluntary disclosure program.

In re Sealed Case, 676 F.2d 793, 800 (D.C. Cir. 1982) (footnotes omitted) (emphasis added). Thus, an effort to extend the reach of certain investigation methods by federal securities regulators because of its potential benefits subsequently caused tension with the underlying principles of the attorneyclient privilege. In this sense, the policy considerations at odds with one another in the current debate over the appropriate limits of the attorney-client privilege for corporations can be seen as being "baked into" the doctrine from its very beginnings. See infra Part IV. 
of determining the nature and magnitude of any payments made by the Upjohn Company or any of its subsidiaries to any employee or official of a foreign government.",85 After completing the investigation-which involved the general counsel or outside counsel sending questionnaires to employees and interviewing eighty-six present and past employees ${ }^{86}$ the company disclosed its preliminary report to the SEC on Form 8-K and provided the IRS with a copy of the report to determine any tax consequences of such payments. ${ }^{87}$ In the end, the total amount of questionable payments came in at $\$ 4,400,000$, or approximately $\$ 24,700,000$ in today's dollars. ${ }^{88}$

Unfortunately for Upjohn, its compliance with the voluntary disclosure program with the SEC did not settle the ongoing IRS investigation into the tax effects of the questionable payments. To the ultimate benefit of the further development of doctrine in the area of the corporate attorney-client privilege, however, the special agents at the IRS decided to press the issue. The agents summoned Upjohn to produce “'[a]ll files relative to the investigation"” including, without limitation, any " "written questionnaires sent to managers of the Upjohn Company's foreign affiliates, and memorandums or notes of the interviews." „89 In essence, the IRS sought to obtain the fruits of the investigation-that is, the information that counsel generated and obtained in connection with the internal investigation-without the invocation of the protection afforded by the attorney-client privilege.

On appeal, the Sixth Circuit applied the control-group test and held that Upjohn must produce any documents outside of the scope of the firm's control group. $^{90}$ The privilege would be limited to "communications made by the so-called 'control group' of the corporation, namely, those officers, usually top management, who play a substantial role in deciding and directing the corporation's response to

85. Upjohn, 449 U.S. at 387 (quoting Upjohn's internal communications).

86. Id.

87. Id.

88. United States v. Upjohn Co., 600 F.2d 1223, 1225 (6th Cir. 1979), rev'd, Upjohn, 449 U.S. 383. Using the U.S. Bureau of Labor Statistics inflation calculator, a sum of $\$ 4,440,000$ in 1971 is equal to $\$ 24,649,669.14$ in 2011. See CPI Inflation Calculator, BUREAU OF LABOR STATISTICS, http://data.bls.gov/cgi-bin/cpicalc.pl. This calculation does assume, however, that the payments made by Upjohn were made entirely in 1971. Upjohn's amended Form 8-K disclosing payments since January 1, 1971 was filed on July 28, 1976; thus, the payments may have occurred throughout that period. See Upjohn, 449 U.S. at 387 \& n.1, 388.

89. Upjohn, 449 U.S. at 387-88 (quoting IRS summons for the production of documents).

90. Upjohn, 600 F.2d at $1224-25$. 
the legal advice given." ${ }^{91}$ The control-group test stood in contrast to the subject-matter test, which would consider all communications made by corporate employees to counsel as being privileged under the traditional

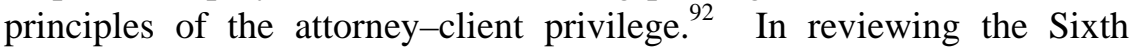
Circuit, however, the Court reversed. It thereby declined to adopt the control-group test and ruled in favor of a more expansive interpretation of the privilege, ${ }^{93}$ subject to certain conditions that are now commonly referred to as "Upjohn warnings." 94

More significantly, however, the Court offered three justifications ${ }^{95}$ for broadly interpreting the scope of the attorney-client privilege: (1) the fundamental distinction between facts and communication; (2) the availability of discovery for the governmental authorities; and (3) the policy interest of preserving full and frank communication between attorneys and their clients. ${ }^{96}$

\section{a. Facts-Communication Distinction}

A critical aspect of the Court's decision in Upjohn is the fundamental distinction between facts and communication. ${ }^{97}$ At first glance, such a distinction may appear rather straightforward and unworthy of further attention or elaboration. The argument presented herein, however, is that the facts-communication distinction is not only fundamental, but could

91. Id. at 1226 .

92. See id. at 1226-27.

93. See Upjohn, 449 U.S. at 395-97.

94. See, e.g., Julie Rose O’Sullivan, The DOJ Risks Killing the Golden Goose Through Computer Associates/Singleton Theories of Obstruction, 44 AM. CRIM. L. REV. 1447, 1467 n.78 (2007). As a matter of practice, the Upjohn warnings function in a manner similar to Miranda warnings in the criminal law context leading to, one supposes, the invention of such a phrase in this area of law. See Miranda v. Arizona, 384 U.S. 436 (1966). Typically, the Upjohn warning provides that, prior to interviewing any employees of the corporation, the interviewing counsel-whether as part of the corporation's law department or from an outside law firm-must advise the interviewee that such counsel represents the corporation and not the interviewee and that the interviewee should consult with his own counsel with respect to any legal issues that may obtain in his or her own circumstance. See O’Sullivan, supra, at 1467 n.78.

95. The notion of justification in the law remains a key area of inquiry in jurisprudence and, while outside the scope of this Article, may provide some insight in which to consider the reasoning of the Court in Upjohn. In particular, this notion may illuminate the grounds upon which the Court decided to reject the control-group test. See, e.g., RONALD DWORKIN, LAW's EMPIRE 190 (1986) ("A conception of law must explain how what it takes to be law provides a general justification for the exercise of coercive power by the state, a justification that holds except in special cases when some competing argument is specially powerful.”).

96. Upjohn, 449 U.S. at 389, 395-96; see infra Part II.B.2.a-c.

97. See Upjohn, 449 U.S. at 395. 
also be determinative of whether the attorney-client privilege should apply to corporations in given cases. On this precise point, and in reviewing the development of the attorney-client privilege as doctrine, one recalls that the Bolton and Greenough opinions set forth the necessary premise of first distinguishing facts from communication. ${ }^{98}$ Accordingly, the question becomes whether such a premise, when considered as part of a longer strand of judicial reasoning, can indeed become the deciding factor in a prudential analysis when determining the applicability of the privilege in given cases. As argued herein, such an approach to this area of law is not only possible, but may well be preferable in its application. ${ }^{99}$

In rejecting the control-group test for the attorney-client privilege, the Upjohn Court reasoned that " $[\mathrm{t}] \mathrm{he}$ privilege only protects disclosure of communications; it does not protect disclosure of the underlying facts by those who communicated with the attorney."100 The Court continued by quoting at length the opinion of the District Court for the Eastern District of Pennsylvania in City of Philadelphia v. Westinghouse Electric Corp.:

[T] he protection of the privilege extends only to communications and not to facts. A fact is one thing and a communication concerning that fact is an entirely different thing. The client cannot be compelled to answer the question, "What did you say or write to the attorney?" but may not refuse to disclose any relevant fact within his knowledge merely because he incorporated a statement of such fact into his communication to his attorney. ${ }^{101}$

Interestingly, in reviewing the pleadings submitted to the Court, Upjohn's counsel cited the above passage from Westinghouse ${ }^{102}$ and noted that "Judge Kirkpatrick, who originated the control-group test,

98. See supra notes $61-62$ and accompanying text.

99. See infra Part IV.

100. Upjohn, 449 U.S. at 395.

101. Id. at 395-96 (alteration in original) (quoting City of Philadelphia v. Westinghouse Elec. Corp. (Westinghouse I), 205 F. Supp. 830, 831 (E.D. Pa. 1962)).

102. Petitioners' Reply Brief, Upjohn, 449 U.S. 383 (No. 79-886), 1980 U.S. S. Ct. Briefs LEXIS 2175 at *8-9 (quoting Westinghouse I, 205 F. Supp. at 831); see also Brief Amici Curiae on Behalf of the American College of Trial Lawyers and 33 Law Firms in Support of Petitioners at Upjohn, 449 U.S. 383 (No. 79-886), 1980 U.S. S. Ct. Briefs LEXIS 2151 at *28-29 (quoting Westinghouse I, 205 F. Supp. at 831) [hereinafter Trial Lawyers Brief]; Brief Amici Curiae for the Committee on Federal Courts and the Committee on Corporate Law Department of the Ass'n of the Bar of the City of New York, Upjohn, 449 U.S. 383 (No. 79-886), 1980 U.S. S. Ct. Briefs LEXIS 2148 at *34-35 (quoting City of Philadelphia v. Westinghouse Elec. Corp. (Westinghouse II), $210 \mathrm{~F}$. Supp. 483, 485 (E.D. Pa. 1962)) [hereinafter N.Y. Bar Brief]. 
explained the rule [of distinguishing facts and communication] in an earlier opinion in that same case.”103 Further, counsel for Upjohn reasoned, "[Upjohn] simply exercised the right, held by any client, to disclose certain facts known to it after first discussing them with its attorneys. Under established authorities, such disclosure does not result in a waiver of the privilege." ${ }^{\prime 04}$ Accordingly, in an interesting turn in doctrinal development, the facts-communication distinction is a shared premise for both the control-group test and subject-matter test. ${ }^{105}$

The Westinghouse case involved a set of interrogatories that sought "detailed information (date, place, individuals present, etc.) of meetings of officials of the defendant corporations and competitors at which prices, territories and terms of sale of electrical equipment were discussed."106 In response, the defense refused to provide most of the information requested in the interrogatories, invoking the attorney-client privilege. ${ }^{107}$ The district court in Westinghouse quickly dispensed of the issue in a decision not exceeding five paragraphs and in a manner that reads almost positively civilian. ${ }^{108}$ Noting that its decision rested on "practically horn-book law and require[d] no elaboration or citation of authorities,"109 the district court focused on the facts-communication distinction as being determinative. ${ }^{110}$ As an additional wrinkle in this line of reasoning, the Westinghouse court further elaborated:

It is too clear to require much discussion that a corporation cannot disclaim knowledge of a fact on the ground that the fact in question has not been communicated to its chief executive officers and board of directors. A corporation acquires knowledge through its officers and agents "and is charged with knowledge of all material facts of which they acquire knowledge while acting in the course of their employment

\footnotetext{
103. Petitioners' Reply Brief, supra note 102 , at $* 8$.

104. Id. at $* 9$.

105. Such an analysis accords with the reading of Bolton and Greenough previously discussed, whereby the facts-communication distinction is a necessary premise-and, indeed, a first principle-for the privilege. See supra notes 37, 61-62 and accompanying text.

106. Westinghouse I, 205 F. Supp. at 830.

107. Id.

108. See id. at 830-31. For further discussion of a comparative perspective on the style of judicial opinions in civil law countries, see, e.g., UGO A. MATTEI, TEEMU Ruskola \& ANTONIO GIDI, SCHLESINGER's COMPARATIVE LAW 555 (7th ed. 2009) (“[M]ost importantly, civil-law countries generally adhere to the rule that every final judgment must be accompanied by a reasoned opinion detailing the position of the court on every major issue of fact and law. ... An ambiguous, incomplete, or contradictory reasoning is reversible error.” (footnotes omitted)).

109. Westinghouse I, 205 F. Supp. at 831.

110. See id.
} 
and within the scope of their authority, even though they do not in fact communicate it."111

Although this language was not specifically quoted by the Court, this further distinction between the knowledge of facts and the communication of such facts to counsel-where, presumably, the communication would be protected by the attorney-client privilege-is consistent with the passage cited with approval in Upjohn. ${ }^{112}$ Indeed, this distinction between the knowledge and communication to counsel of facts may clarify the Court's emphasis in the Upjohn opinion that the protection of the privilege does not extend to "underlying facts." will be discussed, this concept of underlying facts can serve as the foundational premise in a renewed theoretical approach to the problems attending to the privilege in the corporate context. ${ }^{114}$

\section{b. Availability of Discovery}

The second justification upon which the Upjohn Court rested its decision was the availability of discovery by governmental agencies through existing court and administrative procedures. ${ }^{115}$ Although this justification resembles the facts-communication distinction in that it specifically focuses on the facts that may be obtained in the discovery process, one can interpret this strand of thought as constituting separate grounds of justification because of its normative implication-namely, that adversaries in the judicial process should do their own work. ${ }^{116}$ As the Upjohn Court explained:

Here the Government was free to question the employees who communicated with [Upjohn's General Counsel] and outside counsel. Upjohn has provided the IRS with a list of such employees, and the IRS has already interviewed some 25 of them. While it would probably be more convenient for the Government to secure the results of [Upjohn's]

\footnotetext{
111. Id. (emphasis added) (quoting 19 C.J.S. CORPORATIONS $\S 1078$ ).

112. See Upjohn, 449 U.S. at 395-96 (quoting Westinghouse I, 205 F. Supp. at 831).

113. Id. at 395.

114. See infra Part IV.

115. Upjohn, 449 U.S. at 396.

116. For additional discussion of the adversary process and the ongoing debate regarding corporate compliance, see, for example, Miriam Hechler Baer, Governing Corporate Compliance, 50 B.C. L. REv. 949 (2009); David Hess \& Cristie L. Ford, Corporate Corruption and Reform Undertakings: A New Approach to an Old Problem, 41 CoRnell INT'L L.J. 307 (2008); Donald C. Langevoort, Monitoring: The Behavioral Economics of Corporate Compliance with Law, 2002 COLUM. Bus. L. REV. 71 (2002).
} 
internal investigation by simply subpoenaing the questionnaires and notes taken by petitioner's attorneys, such considerations of convenience do not overcome the policies served by the attorney-client privilege. As Justice Jackson noted in his concurring opinion in Hickman v. Taylor: "Discovery was hardly intended to enable a learned profession to perform its functions... on wits borrowed from the adversary."

Accordingly, in making clear that the protection afforded by the privilege extended to corporations when conducting internal investigations, the Court made the normative assessment that governmental authorities should conduct their own investigation into the relevant facts and, further, that no "considerations of convenience" "118 trump the policy considerations in support of the attorney-client privilege. ${ }^{119}$ The precise nature and scope of these policy considerations constitute the third primary justification in Upjohn - namely, that the privilege exists to promote "full and frank communication" between an attorney and her client. $^{120}$

\section{c. Preservation of Full and Frank Communication}

The third and perhaps most compelling justification set forth in Upjohn in favor of the attorney-client privilege is that "[i]ts purpose is to encourage full and frank communication between attorneys and their clients and thereby promote broader public interests in the observance of

117. Upjohn, 449 U.S. at 396 (emphasis added) (citation omitted) (quoting Hickman v. Taylor, 329 U.S. 495, 516 (1947)). For further discussion of the work-product doctrine as enunciated by the Court in Hickman v. Taylor, see infra Part II.B.2.d.

118. Upjohn, 449 U.S. at 396.

119. In an amicus brief, the point was more forcefully put:

In civil cases, the subject matter test does not change the fact that the full panoply of discovery devices made available by the Federal Rules of Civil Procedure may be used by parties opposing a corporate client to discover facts which may also have been communicated to counsel. . . .

... The only "burden" the privilege imposes is that of requiring each party to do its own discovery.

Trial Lawyers Brief, supra note 102, at $* 29$ n.16; see also Brief of the American Bar Ass'n as Amicus Curiae, Upjohn, 449 U.S. 383 (No. 79-886), 1980 U.S. S. Ct. Briefs LEXIS 2152 at*12 ("The attorney-client privilege appropriately fosters and protects the relationship between lawyer and client, but it does not bar discovery of the facts.”); N.Y. Bar Brief, supra note 102, at *15 (" $[\mathrm{N}]$ othing prevents the IRS from determining all of the relevant facts and circumstances concerning questionable payments by Upjohn.”).

120. Upjohn, 449 U.S. at 389. 
law and administration of justice.”121 In making this claim, the Court cited Wigmore's description of the attorney-client privilege and further noted that " $[t]$ he attorney-client privilege is the oldest of the privileges for confidential communications known to the common law." ${ }^{22}$ As previously discussed, however, this assessment of the historical development of doctrine is subject to the criticism that the attorneyclient privilege - in the sense of maintaining in confidence communications between attorney and client, as opposed to initial position of protecting the reputation of the barrister-is anything but a clear and consistent line. ${ }^{123}$

What is clear, however, from this language in Upjohn is that the Court subscribed and fully extended to the corporate form the theoretical justification for the attorney-client privilege as first enunciated by Lord Brougham in Bolton and Greenough. Recall that Lord Brougham spoke to "the interests of justice, which cannot be upholden, and to the administration of justice, which cannot go on, without the aid of men skilled in jurisprudence, in the practice of the Courts, and in those matters affecting rights and obligations which form the subject of all judicial proceedings." 124 In this sense, one can quite naturally draw a line starting with these words from Lord Brougham in Bolton and Greenough and ending at the language from Justice Rehnquist in Upjohn that demonstrates that the purpose of the privilege is to "promote broader public interests in the observance of law and administration of justice."125 Once this theoretical determination in law has been made, the result becomes somewhat natural-the privilege must be protected from compelled disclosure by governmental authorities so that we may uphold the interests in observing law and administering justice. ${ }^{126}$ As a

121. Id.

122. Id. at 389 (citing 8 WIGMORE, supra note 42, § 2290, at 542).

123. Here, one recalls Kant's famous observation: "'Out of the crooked timber of humanity no straight thing was ever made."” Isaiah Berlin, The Pursuit of the Ideal, in THE CROOKED TIMBER OF HUMANITY: CHAPTERS IN THE HISTORY OF IDEAS 19 (Henry Hardy ed., 1990) (quoting Immanuel Kant, Idee zu einer allgemeinen Geschichte in weltbürgerlicher Absicht, 8 KANT's GESAMMELTE SCHRIFTEN 23 (1912)).

124. Greenough v. Gaskell, (1833) 39 Eng. Rep. 618, 621 (Ch.); 1 My. \& K. 88, 103 (emphasis added); see supra note 61 and accompanying text.

125. Upjohn, 449 U.S. at 389.

126. The slight variation in Lord Brougham's language of the "interests of justice" and "administration of justice" as opposed to Justice Rehnquist's phrase "public interests in the observance of law and administration of justice" could make for an intriguing debate as a matter of jurisprudence. Given the scope of this Article, however, such possible lines of inquiry must remain as such. 
consequence, the historical development of the attorney-client privilege up until its extension to the corporate form in Upjohn illustrates quite vividly the importance of first principles in judicial thought. In this manner, the judicial reasoning of Lord Brougham in Bolton and Greenough, as of 1833, echoes to this day within the text of Upjohn and its progeny.

\section{d. Distinction of the Work-Product Doctrine}

In addition to the issues that often arise in relation to the theoretical underpinnings of the attorney-client privilege as set forth in the Upjohn line of cases, a distinction must be made between the attorney-client privilege and the work-product doctrine as enunciated by the Court. ${ }^{127}$ Indeed, the Court in Upjohn specifically noted that the work-product doctrine, ${ }^{128}$ while at issue in the lower court proceedings, was largely a moot point because of the Court's determination that the attorney-client privilege protected most of the documents requested by the IRS. ${ }^{129}$ Nevertheless, the Court noted, in relation to the now-standard test under Rule 26(b)(3) requiring substantial need and undue hardship, ${ }^{130}$ that "a

127. See Upjohn, 449 U.S. at 397 (citing Hickman v. Taylor, 329 U.S. 495 (1947)). As a matter of doctrine, the work-product protection is afforded to materials that were prepared in anticipation of litigation. See Hickman, 329 U.S. at 499-500. Further, work product can either be "factual" work product or "opinion" work product, with the latter receiving a heightened level of protection. See id. at 512-13. Indeed, the court in Hickman noted that if the work product in that case were considered as opinion work product, "[W]e do not believe that any showing of necessity can be made under the circumstances of this case so as to justify production.” Id. at 512.

128. In this Article, I invoke the term "work-product doctrine” because it appears to be the more commonly-used phrase. See, e.g., II EDNA SELAn Epstein, The AtTORnEY-CliEnt PrivileGE AND THE WORK-PRODUCT DOCTRINE 792 (5th ed. 2007) (“The words 'doctrine,' 'immunity,' and 'privilege' (among others) have been used in naming the protection given work product. Any of the terms is probably appropriate.”). This said, the precise phraseology of a given legal rule or action is often subject to one's particular time and circumstance. See, e.g., Christopher T. Hines, Tatsuya Tanigawa \& Andrew P. Hughes, Doing Deals in Japan: An Analysis of Recent Trends and Developments for the U.S. Practitioner, 2006 COLUM. BuS. L. REV. 355, 393 n.94 (2006) (noting that the U.K. term of "takeover bids," in contrast to "tender offers" in the United States, is the preferred language in Japan).

129. See Upjohn, 449 U.S. at 397 (deciding that some content of the counsel's notes and memoranda is not within the attorney-client privilege and turning to a discussion of the workproduct doctrine).

130. Rule 26(b)(3) of the Federal Rules of Civil Procedure codified the holding of the Court in Hickman and provides that a party may discover work product upon a showing of having "substantial need for the materials to prepare its case and cannot, without undue hardship, obtain their substantial equivalent by other means.” FED. R. CIV. P. 26(b)(3)(A)(ii); see Hickman, 329 U.S. at 513 (discussing the possibility of allowing discovery of the documents under certain circumstances). 
far stronger showing of necessity and unavailability by other means ... would be necessary to compel disclosure."131

More specifically, the Court in Upjohn noted how the protections afforded by the attorney-client privilege and the work-product doctrine often overlap within the context of internal investigations. ${ }^{132}$ Making clear this important distinction in doctrine, the Court observed:

The notes and memoranda sought by the Government here, however, are work product based on oral statements. If they reveal communications, they are, in this case, protected by the attorney-client privilege. To the extent they do not reveal communications, they reveal the attorneys' mental processes in evaluating the communications. As Rule 26 and Hickman make clear, such work product cannot be disclosed simply on a showing of substantial need and inability to obtain the equivalent without undue hardship. ${ }^{13}$

While the Court refrained from finding that "such material is always protected by the work-product rule," it did consider the materials as comprising "opinion" work product. ${ }^{134}$

The importance of this doctrinal difference between the attorneyclient privilege and the work-product doctrine is that, in cases involving the work-product doctrine, a party has the possibility of discovering what otherwise may be protected facts by showing substantial need and undue hardship as set forth in Hickman and as now codified in the Federal Rules of Civil Procedure. ${ }^{135}$ While some may reasonably argue that this possibility of discovery in such cases is cumbersome and difficult as a practical matter, the point still remains that, under the auspices of the requirements of substantial need and undue hardship test, a discovering party - in this context, typically the SEC or DOJ in their capacities as enforcers of federal securities law-has an avenue for obtaining the facts in certain circumstances. ${ }^{136}$ Indeed, this focus on exceptions to the

\footnotetext{
131. Upjohn, 449 U.S. at 402.

132. See id. at 397-402.

133. Id. at 401.

134. Id. at 401-02; see supra note 127.

135. See supra note 130.

136. This variation in the line of argument, although it may seem negligible upon first glance, necessarily results in a different debate. Specifically, the issue is no longer whether the material in question - in Upjohn, the notes and memoranda in connection with the internal investigation, or in Hickman, the interview notes by counsel of witnesses to a shipping accident-is protected or not. Rather, the debate centers on whether an exception to the general rule of protection should be granted and, if so, the precise contours of such an exception. In calling for a return to first principles in privilege law, the argument herein is that the debate over exceptions-whether the substantial-
} 
general rules of protection, either by means of the attorney-client privilege or the work-product doctrine, has generated heated discussion among scholars and practitioners alike. The substantial-need and unduehardship exception to the work-product doctrine, as discussed above, exists as a codified federal rule. By contrast, the exception to waiver of the attorney-client privilege that has received the most praise and criticism in recent years - the selective-waiver rule-is born from case law and DOJ policy.

\section{The Ongoing Debate Concerning the Selective-Waiver Rule}

Contemporary debate has focused on whether the waiver of attorney-client privilege should be subject to a selective-waiver exception in cases where a corporation waives the privilege for the benefit of federal securities regulators as a means of exhibiting greater cooperation with the government-and thus, one supposes, a more lenient penalty or final settlement. ${ }^{137}$ The origins of the selective-waiver

need-undue-hardship exception for the work-product doctrine or the selective-waiver rule for the attorney-client privilege-is, in a sense, an ongoing debate over first principles by proxy. Accordingly, in order to provide clarity to doctrine and theory, I place the prudential decision squarely where it belongs - in first determining whether a "fact" or "communication" is at issue.

137. The literature on the topic of selective waiver is considerable, expansive, and ongoing. See, e.g., Lonnie T. Brown, Jr., Reconsidering the Corporate Attorney-Client Privilege: A Response to the Compelled-Voluntary Waiver Paradox, 34 HofSTRA L. REV. 897, 947-51 (2006); Katrice Bridges Copeland, Preserving the Corporate Attorney-Client Privilege, 78 U CIN. L. REV. 1199 (2010); Nancy J. Gegenheimer, The Tenth Circuit Rejects Selective Waiver: Qwest Communications International, Inc. Securities Litigation, 84 DENV. U. L. REV. 775 (2007); Gideon Mark \& Thomas C. Pearson, Corporate Cooperation During Investigations and Audits, 13 STAN. J.L. Bus. \& FIN. 1, 29-41, 63-64, 72 (2007); Colin P. Marks, Corporate Investigations, Attorney-Client Privilege, and Selective Waiver: Is a Half-Privilege Worth Having at All?, 30 SEATTLE U. L. REV. 155 (2006); Julie R. O'Sullivan, Does DOJ's Privilege Waiver Policy Threaten the Rationales Underlying the Attorney-Client Privilege and Work Product Doctrine? A Preliminary "No", 45 AM. CRIM. L. REV. 1237, 1263-66, 1279-80 (2008); Daniel Richman, Decisions About Coercion: The Corporate Attorney-Client Privilege Waiver Problem, 57 DEPAUL L. REV. 295, 306, 321-22 (2008); Liesa L. Richter, Corporate Salvation or Damnation? Proposed New Federal Legislation on Selective Waiver, 76 Fordham L. REV. 129 (2007); Michael L. Seigel, Corporate America Fights Back: The Battle Over Waiver of the Attorney-Client Privilege, 49 B.C. L. REV. 1, 42-43 (2008). In addition, the discussion continues in law review notes. See, e.g., Matthew Altemeier, Note, Rethinking Selective Waiver: The Argument for Mandatory Disclosure, 28 REV. LiTIG. 629 (2009); Stephen A. Calhoun, Note, Globalization's Erosion of the Attorney-Client Privilege and What U.S. Courts Can Do to Prevent It, 87 TEX. L. REV. 235, 257-65 (2008); Erin M. Carter, Note, Pragmatic Selective Waiver: Re-Aligning Corporate Executives' Personal Interests with Those of the Corporation Amidst Government Investigations, 62 VAND. L. REV. 239 (2009); Michelle Lambert, Note, Turning Out the "Light of Reason and Experience": The Selective Waiver Doctrine and Proposed Federal Rule of Evidence 502, 81 ST. JoHN's L. REV. 921 (2007); Andrew J. McNally, Comment, Revitalizing Selective Waiver: Encouraging Voluntary Disclosure of Corporate Wrongdoing by Restricting Third Party Access to Disclosed Materials, 35 SETON HALL L. REV. 823 (2005); 
rule lie with the decision of the Eighth Circuit in the case of Diversified Industries, Inc. v. Meredith. ${ }^{138}$ A close reading of Diversified Industries, however, reveals how the selective-waiver rule-this curious exception to waiver of the attorney-client privilege-began in an almost accidental fashion.

The facts in Diversified Industries resemble those in Upjohn to a considerable degree- a corporation in the copper business faced accusations that it maintained a "slush fund" in order to "bribe purchasing agents of other business entities including Weatherhead[, a company that had purchased large quantities of copper from Diversified], and perhaps for other improper purposes." ${ }^{\prime 39}$ In turn, Weatherhead sued Diversified on numerous grounds, including conspiracy and tortious interference with contractual relationships; Weatherhead further cited section 4 of the Clayton Antitrust Act in its claim for treble damages. ${ }^{140}$ The litigation "attracted the interest" of the SEC and ultimately spurred the SEC to commence an investigation into Diversified and its activities. ${ }^{141}$ In connection with this investigation, Diversified produced to the SEC its internal-investigation report "without protest" in response to an SEC subpoena. ${ }^{142}$

In light of this factual and procedural background, one can view Diversified and Upjohn as being cases from the same stratum of legal development-both of these cases involved companies that found themselves wrapped up in a questionable payments scandal, which ultimately resulted in the enactment of the FCPA and the advent of the SEC's voluntary-disclosure program. ${ }^{143}$ The Eighth Circuit, however, handed down its ruling in Diversified over three years before the Court restated the first principles of privilege law in Upjohn, and thus,

Alexander F. Smith, Comment, Should Congress Adopt Selective Waiver Legislation?, 80 TEMP. L. REV. 595 (2007); Stephen Weigand, Note, Waiver of the Attorney-Client Privilege and Work Product Protection from Thompson to McNulty: A Distinction Without a Difference?, 76 U. CIN. L. REv. 1093 (2008); Katherine M. Weiss, Note, Upjohn Co. v. United States as Support for Selective Waiver of the Attorney-Client Privilege in Corporate Criminal Investigations, 48 B.C. L. REV. 501 (2007).

138. 572 F.2d 596 (8th Cir. 1978) (en banc).

139. Id. at 600 (internal quotation marks omitted).

140. Id.

141. See id.

142. Id. at 599. Diversified did not assert, therefore, the protection of the attorney-client privilege or the work-product doctrine in relation to the subpoena from the SEC. See id.

143. See supra notes $78,84$. 
Diversified did not have Upjohn's guidance upon which to further substantiate its claims. ${ }^{144}$

It is therefore somewhat curious that Diversified, a decision by the Eighth Circuit that pre-dated Upjohn, would in time be considered as espousing the greatest exception to waiver of the attorney-client privilege in this line of cases-the selective-waiver rule. Indeed, the Eighth Circuit only briefly addressed this issue in its en banc opinion. After first determining that the attorney-client privilege protected the materials in question, it observed:

As Diversified disclosed these documents in a separate and nonpublic SEC investigation, we conclude that only a limited waiver of the privilege occurred. To hold otherwise may have the effect of thwarting the developing procedure of corporations to employ independent outside counsel to investigate and advise them in order to protect stockholders, potential stockholders and customers.

In concluding, we note that the litigants are not foreclosed from obtaining the same information from non-privileged sources. ${ }^{145}$

The primary argument, therefore, in support of the selective-waiver ${ }^{146}$ rule as enunciated by the Eighth Circuit in Diversified is a theoretical justification in favor of internal investigations performed by independent outside counsel. As will be further discussed, however, there are other means by which to accomplish these same ends. ${ }^{147}$

As to the selective-waiver rule, its limitations are a matter of frequent discussion and for good reason-the limitations, real and imagined, are quite considerable. Simply stated, the problem with the selective-waiver rule is that it runs afoul of the first principles of privilege law. The question, therefore, as to the selective-waiver rule becomes-how can one selectively waive the privilege when, as a matter of first principles, the communication must be confidential between the

\footnotetext{
144. In particular, Diversified and its counsel did not have the Court's guidance on the "Upjohn warnings" that often come into play when one seeks to protect the privilege when conducting an internal investigation. See supra note 94.

145. Diversified Indus., 572 F.2d at 611 (emphasis added) (citations omitted) (citing Bucks Cnty. Bank \& Trust Co. v. Storck, 297 F. Supp. 1122 (D. Haw. 1969); United States v. Goodman, 289 F.2d 256, 259 (4th Cir.), vacated on other grounds per curiam, 368 U.S. 14 (1961)).

146. Although the Eighth Circuit in Diversified discussed a "limited waiver," see id., in time the more commonly used phrase became "selective waiver," see supra notes 128,137 , which is the term used throughout this Article.

147. See infra Part IV.A.
} 
attorney and the client? ${ }^{148}$ Further, how can one claim that the SEC or DOJ, in the context of enforcing federal securities laws, should be viewed as either the client itself or its attorney? ${ }^{149}$

The problem for the selective-waiver rule, unfortunately, is that these questions do not appear to have any satisfactory answers. In truth, the selective-waiver rule is not so much a rule for waiving the privilege, but instead operates in a manner similar to a safe-harbor rule for certain disclosures to governmental entities. And, in turn, this dilutes the primary justification for the privilege in the first instance- the "interests of justice" and "administration of justice" as explicated by Lord Brougham in Bolton and Greenough. ${ }^{150}$ For what is the privilege worth as a principle of law if it can be selectively applied in some cases and selectively waived in others? ${ }^{151}$

It should not be surprising, therefore, that the federal circuit courts have in large measure rejected the application of the selective-waiver rule. $^{152}$ In one of the more recent opinions that sharply criticized the

148. See, e.g., Restatement (ThiRd) OF the LaW Governing LaWyers $\S 68$ (2000). The Restatement (Third) observes that the attorney-client privilege extends to "(1) a communication (2) made between privileged persons (3) in confidence (4) for the purpose of obtaining or providing legal assistance for the client.” Id. (emphasis added).

149. In the language of the Restatement (Third), the question would be whether the SEC or DOJ qualified as "privileged persons." See id. at § 70 ("Privileged persons within the meaning of § 68 are the client (including a prospective client), the client's lawyer, agents of either who facilitate communications between them, and agents of the lawyer who facilitate the representation."). Although one could make an argument that the SEC or DOJ might qualify as an "agent" of either the client or its attorney, such an argument does not appear to be particularly persuasive.

150. See supra Part II.A.

151. On this point, it may be helpful to recall that the attorney-client privilege in its operation often serves as a rule of evidence by deeming certain materials or testimony as beyond the permissible scope of discovery by private litigants or governmental authorities. See, e.g., Upjohn Co. v. United States, 449 U.S. 383, 386 (1981). Accordingly, a rule permitting certain adverse parties, here the federal securities regulators, to obtain the "fruits of the investigation" while denying others - most likely plaintiffs in either a private securities class action or a derivative suit on behalf of the corporation - would, one may argue, strike at the very heart of the integrity of the adversarial process.

152. See Burden-Meeks v. Welch, 319 F.3d 897, 899 (7th Cir. 2003) ("Knowing disclosure to a third party almost invariably surrenders the privilege with respect to the world at large; selective disclosure is not an option.” (citing Dellwood Farms, Inc. v. Cargill, Inc., 128 F.3d 1122, 1126-27 (7th Cir. 1997); United States v. Hamilton, 19 F.3d 350, 353 (7th Cir. 1994))); In re Columbia/HCA Healthcare Corp. Billing Practices Litig., 293 F.3d 289, 302 (6th Cir. 2002) (“[W]e reject the concept of selective waiver, in any of its various forms.”); United States v. Mass. Inst. of Tech., 129 F.3d 681, 686-87 (1st Cir. 1997) (rejecting doctrine of selective waiver); In re Steinhardt Partners, 9 F.3d 230, 235-36 (2d Cir. 1993) (rejecting doctrine of selective waiver); Westinghouse Elec. Corp. v. Republic of the Philippines, 951 F.2d 1414, 1423-25 (3d Cir. 1991) (rejecting doctrine of selective waiver); In re Subpoenas Duces Tecum, 738 F.2d 1367, 1369-70 (D.C. Cir. 1984) (rejecting doctrine of selective waiver); Permian Corp. v. United States, 665 F.2d 1214, 1219-21 (D.C. Cir. 1981) (rejecting doctrine of selective waiver); but see In re McKesson HBOC, Inc. Sec. 
selective-waiver rule, the Sixth Circuit squarely framed the issue in noting that it could not find any reason in law or policy to transform either the attorney-client privilege or work-product doctrine into "another 'brush on the attorney's palette,' used as a sword rather than a shield." 153 This notion of using privilege law as either a sword or a shield, depending on the particular litigation strategy in a given case, is the precise theoretical weakness of the selective-waiver rule. In permitting a corporation to selectively invoke privilege law to further its particular interests, the theoretical foundation of the attorney-client privilege — and by extension the work-product doctrine--begins to crack. As Lord Brougham first observed in Bolton and Greenough, the modern attorney-client privilege must speak to the larger interests and administration of justice. ${ }^{154}$ Accordingly, there exists a void in the existing doctrine and theory because the debate has strayed from the first principles of privilege law. ${ }^{155}$

\section{THE EVOLUTION OF THE ENFORCEMENT OF FEDERAL SECURITIES LAW AND THE WAIVER OF THE ATTORNEY-CLIENT PRIVILEGE}

In concert with the historical development of the attorney-client privilege, as discussed in Part II, in the thirty years since the Court decided Upjohn we have witnessed significant change as to how the waiver of the attorney-client privilege often works as a matter of practice as part of the greater evolution of the enforcement of federal securities law. ${ }^{156}$ Accordingly, this Part summarizes some of the more notable changes in law and practice by addressing the following points of interest: (a) the advent of attorneys as "gatekeepers" of the corporation as described by the SEC in Carter \& Johnson; ${ }^{157}$ (b) the changes in SEC and DOJ enforcement guidelines that, in form and substance, highlighted the possible waiver of the attorney-client privilege; ${ }^{158}$ and (c) an analysis

\footnotetext{
Litig., No. C-99-20743 RMW, 2005 U.S. Dist. LEXIS 7098, at*41-46 (N.D. Cal. Mar. 31, 2005) (finding that disclosure to the government pursuant to a confidentiality agreement preserves the work-product protection).

153. In re Columbia/HCA, 293 F.3d at 307 (quoting In re Steinhardt, 9 F.3d at 235).

154. See supra Part II.A.

155. See infra Part IV.

156. See generally Thomas Lee Hazen, The LaW of Securities Regulation § 16.2 (6th ed. 2009); Joel Seligman, The Transformation of Wall Street: A History of the Securities AND EXCHANGE COMMISSION AND MODERn CORPORATE FINANCE 622-744 (3d ed. 2003).

157. See infra Part III.A.

158. See infra Part III.B.
} 
of selected SEC enforcement actions to the extent discernible from the publicly available data. ${ }^{159}$

\section{A. The Advent of the Attorney as Gatekeeper}

A significant starting point in considering the development of what has been deemed a "culture of waiver" 160 in the enforcement of federal securities law in recent years is the emerging role of the attorney as gatekeeper for the corporate enterprise. ${ }^{161}$ Although the intersection of legal ethics and federal securities law is a complex topic, ${ }^{162}$ this discussion focuses on two seminal events - the SEC's action against two attorneys in Carter \& Johnson that first developed the notion of an attorney as gatekeeper in the context of federal securities law and the ultimate triumph of such an approach with the enactment of section 307 of the Sarbanes-Oxley Act. ${ }^{163}$

Although Carter \& Johnson may be viewed as a vestige of history, ${ }^{164}$ it sets the stage for the development of the current view of attorneys in securities regulation. The SEC brought an action against two attorneys who represented a corporate client under what is now Rule 102(e) of the SEC Procedural Rules and sought possible suspension or disbarment in respect to appearing or practicing before the SEC. ${ }^{165}$ The facts of the case involved disclosure issues surrounding a corporation's seeking additional financing because of its dire business results, which eventually

159. See infra Part III.C.

160. See Seigel, supra note 137, at 5 n.30 (citing Jason McClure, Unlikely Alliance, 53 MiAmI DAILY Bus. REV., Dec. 20, 2006) (noting that although seventy-five percent of corporate counsel in a 2006 study by the Association of Corporate Counsel and the National Association of Criminal Defense Lawyers subscribed to the notion of a culture of waiver, "[i]n light of the obvious bias of the surveyors and the population surveyed, this statistic is meaningless").

161. See generally COFFEE, supra note 35, at 192-244.

162. See id. at 209-12; Milton C. Regan, Jr., Foreword: Professional Responsibility and the Corporate Lawyer, 13 GeO. J. LegAL ETHICS 197, 205-07 (2000) (discussing the unique ethical tensions faced by corporate attorneys).

163. See Public Company Accounting Reform and Investor Protection Act, Pub. L. No. 107-204, $\S 307,116$ Stat. 745, 784 (2002) (codified as 15 U.S.C. § 7245 (2006)). Pursuant to the congressional mandate set forth in section 307 of the Sarbanes-Oxley Act, see id., the SEC promulgated certain standards of professional conduct for attorneys. See Standard of Professional Conduct for Attorneys Appearing and Practicing Before the Commission in the Representation of an Issuer, 17 C.F.R. §§ 205.1-.7 (2011).

164. See COFFEE, supra note 35, at 212 ("The SEC has not subsequently brought an enforcement action against an attorney under Rule 102(e), except in cases where the attorney has been criminally convicted.”).

165. Carter \& Johnson, Exchange Act Release No. 17597, [1981 Transfer Binder] Fed. Sec. L. Rep. (CCH) ๆ 82,849 (Feb. 28, 1981), at 84,146. 
forced it into bankruptcy. ${ }^{166}$ As to the specific allegation that the attorneys aided and abetted violations of federal securities law perpetrated by their client when issuing misleading and incomplete disclosures, ${ }^{167}$ the SEC found that neither of the attorneys had the necessary level of intent to substantiate such a charge since they "did not intend to assist the violations by their inaction or silence." ${ }^{168}$ Instead, the SEC arrived at what appears to be the reasonable conclusion that the attorneys "seemed to be at a loss for how to deal with a difficult client."169

The SEC, however, set forth new interpretative guidance on the standards of professional conduct for attorneys practicing before the SEC. ${ }^{170}$ Specifically, while noting that "precise standards have not yet emerged," ${ }^{171}$ the SEC thereafter observed:

When a lawyer with significant responsibilities in the effectuation of a company's compliance with the disclosure requirements of the federal securities laws becomes aware that his client is engaged in a substantial and continuing failure to satisfy those disclosure requirements, his continued participation violates professional standards unless he takes prompt steps to end the client's noncompliance. ${ }^{172}$

This new standard-with "substantial and continuing failure" trigger for a possible violation of the legal ethics of securities

166. For the experienced securities-regulation attorney, such a fact pattern will appear quite familiar. A more recent example of this type of case can arguably be seen in the dispute concerning alleged misstatements made by Bank of America in connection with its merger with Merrill Lynch at the height of the financial crisis. Louise Story, Judge Accepts S.E.C.'s Deal with Bank of America, N.Y. TiMES, Feb. 23, 2010, at B1. Specifically, the misstatements in question concerned certain bonus payments owed to Merrill Lynch executives and the mounting losses at Merrill Lynch that ultimately coincided with a second government bailout of $\$ 20$ billion. Id. After rejecting an initial settlement that included \$33 million in penalties, Judge Rakoff of the Southern District of New York approved a $\$ 150$ million settlement, which he deemed as “"half-baked justice at best.” Id. As Judge Rakoff further observed, “'This court, while shaking its head, grants the S.E.C.'s motion and approves the proposed consent judgment."” Id.

167. Specifically, the violations related to Section 10(b) and 13(a) of the Exchange Act and Rules 10b-5, 12b-20, and 13a-11 thereunder. Carter \& Johnson, [1981 Transfer Binder] Fed. Sec. L. Rep. (CCH) at 84,146.

168. Id. at 84,169 .

169. Id. One may assume that this is a circumstance in which many securities attorneys can, whether through general knowledge or past experience, readily empathize.

170. See id. at 84,169-73.

171. Id. at 84,170 .

172. Id. at 84,172 (emphasis added).

173. Id. 
attorneys-provides the lasting impact of Carter \& Johnson. ${ }^{174}$ This new approach to the intersection of federal securities law and legal ethics only came to full fruition with the passage of section 307 of the Sarbanes-Oxley Act.

In the aftermath of the accounting scandals of Enron, WorldCom, Adelphia, and others, Congress enacted the Sarbanes-Oxley Act as a means of enhancing federal criminal and securities laws. ${ }^{175}$ As part of these reforms, section 307 of Sarbanes-Oxley-a provision inserted into the bill by then-Senator John Edwards of North Carolina ${ }^{176}$ —provided for the SEC to promulgate rules of professional responsibility for attorneys appearing and practicing before the SEC. ${ }^{177}$ The resulting final rules set forth the now-famous "up-the-ladder" reporting requirements under the Attorney Conduct Rules. ${ }^{178}$ Although the final rule omitted the controversial "noisy withdrawal" requirement as set forth in an early draft of the rule, ${ }^{179}$ the drafters fully realized Carter \& Johnson's potential impact on the professional conduct of attorneys appearing and practicing before the SEC. ${ }^{180}$ The advent of the corporate attorney as gatekeeper was now at hand. ${ }^{181}$

174. As Professor Coffee further explains, however,

The bar knew that [Carter \& Johnson] had been issued by the "old" SEC under its Democratic chairman, Harold Williams, in early 1981, just days before a new Republican SEC chairman appointed by newly elected President Ronald Reagan was to replace Chairman Williams. That new Commission, under Chairman John Shad, showed no inclination to implement [Carter \& Johnson] with proposed rules. Not only was the decision's name rarely spoken, but in 1982 the Commission's general counsel delivered a conciliatory speech in which he predicted that the Commission would normally limit its discipline of attorneys to instances where the conduct also violated established ethical rules of state bar organizations.

COFFEE, supra note 35, at 211-12 (footnotes omitted) (citing Edward Green, Lawyer Disciplinary Proceedings Before the Securities and Exchange Commission, 14 Sec. Reg. \& L. Rep. (BNA) 168 (Jan. 3, 1982)).

175. See id. at $81,216-17$.

176. Id. at $216-17$.

177. Sarbanes-Oxley Act, 15 U.S.C. § 7245 (2006).

178. See Standards of Professional Conduct for Attorneys Appearing and Practicing Before the Commission in the Representation of an Issuer, 17 C.F.R. § 205.3 (2011); COFFEE, supra note 35, at 218-20.

179. See COFFEE, supra note 35, at 220-23 (discussing the controversial proposed "noisy withdrawal" rule).

180. See 17 C.F.R. §§ 205.1-.7. In brief, the Attorney Conduct Rules provide that an attorney appearing and practicing before the SEC has the duty to report up the ladder of her corporate client in the event that she becomes aware of evidence of a "material violation" of federal securities laws and there is not an "appropriate response" within a reasonable amount of time. Id. § 205.3(b).

181. For further discussion of the evolving issues in this area of law, see Michele DeStefano Beardslee, Taking the Business Out of Work Product, 79 ForDHAM L. REV. 1869 (2011), Sung Hui 


\section{B. SEC and DOJ Enforcement Guidelines}

In parallel with the advent of the corporate attorney as gatekeeper, the SEC and the DOJ modified their policy positions respecting the regulation and enforcement of federal securities laws. Specifically, over the course of the past decade, both the SEC and the DOJ took the position that they would consider the waiver of the attorney-client privilege as a positive factor in the determination of an appropriate settlement with the defendant in question. ${ }^{182}$ This initial position, however, softened over time as the outcry from industry and the bar over the "culture of waiver" 183 effectively compelled the federal regulators to reassess their policies. ${ }^{184}$

\section{SEC Enforcement Guidelines}

The SEC first established its policy regarding the possible waiver of the attorney-client privilege in what has now been termed as the Seaboard Report. ${ }^{185}$ In notable part, the Seaboard Report sets forth guidance on "best practices" for public companies when confronted with possible violation of federal securities laws by one of its employees. In the case at issue in the Seaboard Report, a former controller at a subsidiary of a public corporation allegedly misstated certain periodic reports and then engaged in a cover-up. ${ }^{186}$ Once this came to light, the parent corporation appointed outside counsel to lead an internal investigation, dismissed the former controller and two other employees, and disclosed to the market its need to restate its financial statements. ${ }^{187}$ Importantly,

Kim, Gatekeepers Inside Out, 21 Geo. J. Legal Ethics 411 (2008), and Sung Hui Kim, Lawyer Exceptionalism in the Gatekeeping Wars, 63 S.M.U. L. REV. 73 (2010).

182. See infra Part III.B.1 (examining the SEC’s position).

183. See supra note 160 and accompanying text.

184. Admittedly, one may contest the assertion that either the SEC or DOJ felt compelled to change policy in light of the reaction of industry and the bar. On this point, please note that I do not necessarily take a position for or against any specific policies of the federal securities regulators. Rather, my effort here is to draw a light on the interplay between the SEC and DOJ and those that they regulate and the ever-evolving nature of the enforcement of federal securities law.

185. See Report of Investigation Pursuant to Section 21(a) of the Securities Exchange Act of 1934 and Commission Statement on the Relationship of Cooperation to Agency Enforcement Decisions, Exchange Act Release No. 44969, [2001-2003 Transfer Binder] Fed. Sec. L. Rep. (CCH) I 74,985 (Oct. 23, 2001) [hereinafter Seaboard Report].

186. Id. at 63,195 .

187. Id. 
[t]he company pledged and gave complete cooperation to our staff. ... . [T] he company produced the details of its internal investigation, including notes and transcripts of interviews . . . and it did not invoke the attorney-client privilege, work product protection or other privileges or protections with respect to any facts uncovered in the investigation. ${ }^{188}$

As a result of the parent corporation's cooperation, the SEC took no action against the corporation in this matter. ${ }^{18}$

As a means of further defining the appropriate extent of cooperation with the SEC, the Seaboard Report sets forth a series of questions for public corporations that inquire into the nature and detection of misconduct. ${ }^{190}$ Most importantly for privilege law, however, the SEC posed the question: "Did the company promptly make available to our staff the results of its review and provide sufficient documentation reflecting its response to the situation?"191 The upshot, therefore, of the Seaboard Report is that public companies were effectively incentivized to waive, or forgo asserting, the attorney-client privilege or workproduct doctrine in order to obtain a favorable settlement result with the SEC. ${ }^{192}$

188. Id.

189. Id.

190. Id. at 63,196

191. Id. at 63,197. In an extensive footnote to the Seaboard Report, the SEC noted that

[i]n some cases, the desire to provide information to the Commission staff may cause companies to consider choosing not to assert the attorney-client privilege, the work product protection and other privileges, protections and exemptions with respect to the Commission. The Commission recognizes that these privileges, protections and exemptions serve important social interests. In this regard, the Commission does not view a company's waiver of a privilege as an end in itself, but only as a means (where necessary) to provide relevant and sometimes critical information to the Commission staff. Thus, the Commission recently filed an amicus brief arguing that the provision of privileged information to the Commission staff pursuant to a confidentiality agreement did not necessarily waive the privilege as to third parties. Moreover, in certain circumstances, the Commission staff has agreed that a witness' production of privileged information would not constitute a subject matter waiver that would entitle the staff to receive further privileged information.

Id. at 63,197 n.3 (emphasis added) (citation omitted). Although the SEC's explication of its reasoning on this point appears persuasive, the problem is that the courts have not necessarily agreed with the position that producing otherwise-privileged documents to the federal securities regulators under the terms of a confidentiality agreement will ensure that such documents will remain privileged against, for example, private plaintiffs in a federal securities class action. See supra note 152 and accompanying text. Accordingly, it would appear that the selective-waiver line of cases has effectively thwarted this potential compromise.

192. See Seaboard Report, supra note 185, at 63,197 ("Did the company voluntarily disclose information our staff did not directly request and otherwise might not have uncovered? Did the company ask its employees to cooperate with our staff and make all reasonable efforts to secure such 
As a possible reaction to some of the perceived excesses of the policies set forth in the Seaboard Report-in particular, the concerns of industry regarding the increase in penalties ${ }^{193}$ - the SEC provided further guidance in 2006 on the issue of financial penalties. ${ }^{194}$ The new guidelines focused on "[t]he presence or absence of a direct benefit to the corporation as a result of the violation", 195 and "[t]he degree to which the penalty will recompense or further harm the injured shareholders.”196 Although an additional procedure announced in 2007 provided that enforcement attorneys would need the approval of commissioners prior to negotiating corporate penalties, ${ }^{197}$ such efforts were terminated by Chairman Mary Schapiro in 2009. ${ }^{198}$ Accordingly, while much of the substance of the Seaboard Report is now subject to subsequent guidelines and policy directives, the essential question that the Seaboard Report presents in respect to the possible waiver of the attorney-client privilege remains, as of today, an unsettled one.

\section{DOJ Enforcement Guidelines}

In a manner similar to that used by the SEC in the development of its policy positions, the DOJ outlined its stance in the "Holder Memo."199 The Holder Memo first took the position that the waiver of the attorneyclient privilege would be considered a positive factor in terms of corporate cooperation with federal authorities under certain guidelines for federal prosecution of corporations. ${ }^{200}$ In many ways, the

cooperation?").

193. For additional discussion of certain statistical results during this time period, see infra Part III.C.

194. See Press Release, Sec. \& Exch. Comm'n, Statement of the Securities and Exchange Commission Concerning Financial Penalties (Jan. 4, 2006), http://www.sec.gov/news/press/20064.htm [hereinafter Financial Penalties Guidelines]; Christopher Cox, Chairman, Sec. \& Exch. Comm'n, Statement of Chairman Cox Concerning Objective Standards for Corporate Penalties (Jan. 4, 2006), http://www.sec.gov/news/speech/spch010406cc.htm.

195. Financial Penalties Guidelines, supra note 194.

196. Id.

197. See Jesse Westbrook \& David Scheer, Cox's SEC Hindered Probes, Slowed Cases, Shrank Fines, GAO Says, BLOOMBERG (May 6, 2009), http://www.bloomberg.com/apps/news?pid= newsarchive\&sid=aPus5C5B.JhQ.

198. See Mary L. Shapiro, Chairman, Sec. \& Exch. Comm'n, Address to Practising Law Institute's “SEC Speaks in 2009” Program (Feb. 6, 2009), available at http://www.sec.gov/ news/speech/2009/spch020609mls.htm.

199. The memorandum owes its name to then-Deputy Attorney General, and current Attorney General, Eric Holder.

200. See Memorandum from Eric Holder, Deputy Attorney Gen., to All Component Heads \& U.S. Attorneys on Bringing Criminal Charges Against Corps. (Jun. 16, 1999), 
development of the DOJ enforcement guidelines with respect to the waiver of the attorney-client privilege is the story of multiple memoranda. Beginning with the Holder Memo, the issue of the waiver of the attorney-client privilege was identified as follows:

One factor the prosecutor may weigh in assessing the adequacy of a corporation's cooperation is the completeness of its disclosure including, if necessary, a waiver of the attorney-client and work product protections, both with respect to its internal investigation and with respect to communications between specific officers, directors, and employees and counsel.... The Department does not, however, consider waiver of a corporation's privileges an absolute requirement, and prosecutors should consider the willingness of a corporation to waive the privileges when necessary to provide timely and complete information as only one factor in evaluating the corporation's cooperation. ${ }^{201}$

The Holder Memo further noted that waiver requests made by prosecutors to corporations should typically be limited to factual work product and not address the core opinion work product that the privilege is designed to protect. ${ }^{202}$ Subsequently, this language from the Holder Memo found its way into the next memorandum of interest-the "Thompson Memo."203

Although the Thompson Memo tracked the language of the Holder Memo on the issue of the waiver of the attorney-client privilege, there is one noticeable difference between the two memoranda-the date. One must therefore consider the Thompson Memo as a document from its time- the Internet bubble had popped, Sarbanes-Oxley had just been enacted, and investigations into Enron and WorldCom had commenced. $^{204}$ Accordingly, while the specific language contained in DOJ's guidance may not have changed, certainly the context in which it

http://federalevidence.com/pdf/Corp_Prosec/Holder_Memo_6_16_99.pdf.

201. Id. at 7 (emphasis added).

202. Id. at $14 \mathrm{n} .2$ ("This waiver should ordinarily be limited to the factual internal investigation and any contemporaneous advice given to the corporation concerning the conduct at issue. Except in unusual circumstances, prosecutors should not seek a waiver with respect to communications and work product related to advice concerning the government's criminal investigation.”).

203. See Memorandum from Larry D. Thompson, Deputy Attorney Gen., to Heads of Dep't Components \& U.S. Attorneys on Principles of Fed. Prosecution of Bus. Orgs. (Jan. 20, 2003), http://www.justice.gov/dag/cftt/corporate_guidelines.htm [hereinafter Thompson Memo].

204. See Ved P. Nanda, Corporate Criminal Liability in the United States: Is a New Approach Warranted?, 58 AM. J. COMP. L. 605, 606-07, 624 (2010). Indeed, the Thompson Memo itself clearly identifies its guidance as being an outgrowth of the work performed by the DOJ in connection with its Corporate Fraud Task Force. See Thompson Memo, supra note 203, at 1. 
applied was notably and necessarily different. In light of the aggressive response of federal prosecutors to the accounting fraud scandals, certain quarters felt that the prosecutors were going too far. ${ }^{205}$ As a consequence, the Thompson Memo became something of a cause célèbre within the industry and the bar, resulting in congressional proposals to mandate guidelines for waiver of the attorney-client privilege at the various federal agencies. ${ }^{206}$

In an effort to address some of the concerns raised in response to the Thompson Memo, the DOJ issued the "McCallum Memo" in 2005. ${ }^{207}$ While the McCallum Memo did not deviate from the language set forth in the Thompson Memo-and by extension the Holder Memo-it did provide for the additional direction that the recipients thereto "establish a written waiver review process for your district or component" but that "[s]uch waiver review processes may vary from district to district (or component to component)."208 Unsurprisingly, this addendum did not satisfy the concerns raised, which had to wait until the arrival of the fourth memorandum - the "McNulty Memo."209 In notable part, the McNulty Memo expressly "supersede[d] and replace[d]" the Thompson Memo and McCallum Memo. ${ }^{210}$ Further, the McNulty Memo struck the language concerning the waiver of the attorney-client privilege that echoed the Holder Memo ${ }^{211}$ and provided for a new distinction between "Category I" and "Category II" privileged information-that is, between "factual" information and "opinion" information. ${ }^{212}$ Finally, the

205. See Christopher A. Wray \& Robert K. Hur, Corporate Criminal Prosecution in a PostEnron World: The Thompson Memo in Theory and Practice, 43 AM. CRIM. L. REV. 1095, 1095, 1170-74 (2006) (discussing some of the criticism directed at the Thompson Memo and federal prosecutors).

206. See Press Release, Am. Bar Ass'n, Introduction in U.S. House of Representatives. 4326, The Attorney-Client Privilege Protection Act of 2009 (Dec. 17, 2009), http://apps.americanbar.org/ abanet/media/statement/statement.cfm?releaseid=847.

207. See Memorandum from Robert D. McCallum, Jr., Acting Deputy Attorney Gen., to Heads of Dep't Components \& U.S. Attorneys, Waiver of Corporate Attorney-Client and Work Product Protection (Oct. 21, 2005), http://lawprofessors.typepad.com/whitecollarcrime_blog/files/Attorney ClientWaiverMemo.pdf.

208. Id. at 1.

209. See Memorandum from Paul J. McNulty, Deputy Attorney Gen., to Heads of Dep't Components \& U.S. Attorneys on Principles of Fed. Prosecution of Bus. Orgs. (Dec. 12, 2006), http://www.justice.gov/dag/speeches/2006/mcnulty_memo.pdf.

210. Id. at 2.

211. Id. at 6 (discussing those factors to be considered by prosecutors in deciding to charge a corporation).

212. Id. at 11-12 (defining Category I information as "purely factual information, which may or may not be privileged, relating to the underlying misconduct" and defining Category II information as "attorney-client communications or non-factual attorney work product"). 
McNulty Memo provided for consultation with Main Justice prior to any field office's obtaining the requisite authority to make a waiver request to a given corporation. ${ }^{213}$

The import of these reforms is clear-an effort by the DOJ, and specifically Main Justice, to regain control of a process that, whether real or imagined, seems to have spun out of control. ${ }^{214}$ On these points, even Attorney General Holder noted that issues related to the waiver of the attorney-client privilege evolved in ways that were unforeseen in 1999..$^{215}$ Although it appears that the McNulty Memo and its associated reforms have achieved some consensus among prosecutors, the industry, and the bar, ${ }^{216}$ the question of when to seek a waiver request from a corporation remains controversial within the profession.

\section{Analysis of Recent Trends in Securities Law Enforcement}

As a means of providing additional insight into recent trends in the enforcement of federal securities law and in concert with the previous discussion of SEC and DOJ enforcement guidelines, this section sets forth a statistical analysis of selected SEC enforcement actions to the extent that can be determined from the publicly available data. ${ }^{217}$

This analysis is derived from a review of selected SEC enforcement actions between January 1, 2000 and December 31, 2010, which are available on LexisNexis electronic resources. The analyzed sample

213. See id.

214. See id. at 1-2 (praising the Department's success in prosecuting fraud but noting concern in the corporate legal community with regard to some Department practices); Press Release, Dep't of Justice, Justice Department Revises Charging Guidelines for Prosecuting Corporate Fraud, http://www.justice.gov/opa/pr/2008/August/08-odag-757.html (“[C]redit for cooperation will not depend on the corporation's waiver of attorney-client privilege or work product protection, but rather on the disclosure of relevant facts.").

215. Peter Lattman, The Holder Memo and Its Progeny, WALL St. J. (Dec. 23, 2006), http://blogs.wsj.com/law/2006/12/13/the-holder-memo/ (“'I thought it was a worthwhile endeavor but didn't expect these issues would become as big as they were,' says Holder . . . .”).

216. See id. (“[Holder] applauds McNulty's changes. 'Today, it’s maddening,' he says. 'You'll go into a prosecutor's office ... . and fifteen minutes into our first meeting they [ask if you are going to waive.]'”); see also Cindy A. Schipani, The Future of the Attorney-Client Privilege in Corporate Criminal Investigations, 34 DEL. J. CoRP. L. 921, 963 (2009) ("Yet it is possible that the 2008 Guidelines may strike a new balance between protection of the attorney-client privilege and the efficient prosecution of corporate crime.”).

217. I especially thank Brett D. Kolditz and Priti Nemani for their tireless assistance in respect of this review of the selected SEC enforcement actions. An unabridged copy of these research findings, consisting of a 405-page report, is available on file with the author. See Master Index of Materials Reviewed: SEC Enforcement Actions from January 1, 2000 to December 31, 2010 (Jan. 31,2011 ) (on file with author). 
compiles SEC investigations resulting in a settlement, disgorgement, or fine amount exceeding $\$ 1,000,000 .^{218}$

The search terms used to produce the analyzed sample aim to establish a materiality threshold that captured the more significant amounts in settlements, penalties, or fines that resulted from the final resolution of the relevant SEC enforcement action. ${ }^{219}$ As a consequence, this analysis, as well as any conclusions that may be drawn from the underlying data, does not constitute a complete analysis of all the available public information. ${ }^{220}$ This said, I designed the analysis with the aim of providing specific statistical results that may be helpful in obtaining a more complete understanding of the various trends in federal securities law and practice.

Figure 1 sets forth the results of this statistical analysis. It illustrates that, out of the sample set of 1,471 SEC enforcement actions, only nine cases involved the waiver of the attorney-client privilege or workproduct doctrine. ${ }^{22}$

218. See id.; see also SEC Decisions, Orders \& Releases, LEXISNeXIS, http://www.lexis.com (after logging in, navigate to "Find a Source" section; search and then select "SEC Decisions, Orders \& Releases”). The analyzed sample was selected by searching LexisNexis's SEC Decisions, Orders, \& Releases database using the following search string: "million! or billion! w/20 penalt! or settle! or fine! or disgorge! and date(geq(01/01/2000) and leq(12/31/2010)).” This search results in 1,472 documents - or $4.14 \%$ of the 35,523 total documents for the same period available in the database. See supra note 217.

219. The public availability of information necessarily limits this analysis. For instance, to the extent that a certain corporation waived the attorney-client privilege as part of an informal or formal SEC investigation that never resulted in an enforcement action, such a waiver will not have been disclosed in a final SEC enforcement release-that is to say, no enforcement proceedings commenced as a result of the investigatory process. See SEC. \& EXCH. COMM'N, ENFORCEMENT MANUAL §§ 2.3-2.6 (2010), available at http://www.sec.gov/divisions/enforce/enforcement manual.pdf. Further, even when the SEC commences an enforcement action, the possibility exists that the waiver of the attorney-client privilege remained undisclosed in the relevant SEC enforcement release. While this latter scenario may appear more remote, such a limitation in the publicly available data remains a possibility.

220. Although reasonable minds may disagree on an appropriate search term for the relevant documents, the search string employed, see supra note 218 , intentionally provided some limitation on the amount of materials to be reviewed and ensured the compilation of a sample comprising a useful set of data. As background, the review of these selected SEC documents took place over a period of five months and constitutes approximately 400 total hours of research and related assistance. Assuming this rate in the research process, a complete review of all 35,523 documents would have required an additional 9,660 hours-approximately one year and one month of additional, uninterrupted research and related assistance.

221. See State St. Bank \& Trust Co., Securities Act Release No. 9107, 2010 SEC LEXIS 1018, at *27-28 (Feb. 4, 2010) (limited privilege waiver); MBIA, Inc., Securities Act Release No. 8776, Exchange Act Release No. 55184, 2007 SEC LEXIS 171, at *37-38 (Jan. 29, 2007) (prospective waiver of any applicable privilege with respect to internal investigation, upon written request by SEC staff); Statoil, ASA, Exchange Act Release No. 54599, 2006 SEC LEXIS 2321, at *13-14 (Oct. $13,2006)$ (voluntary production of documents privileged by the attorney-client privilege pursuant to 


\section{Figure 1: Analysis of Selected SEC Enforcement Actions}

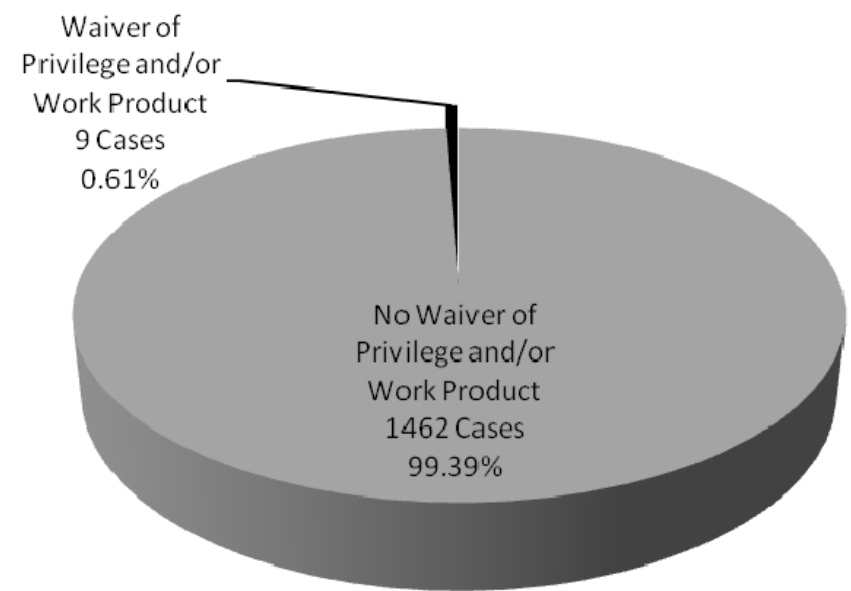

Accordingly, one may conclude that-at least based on this sample of publicly available data-the issue of waiver of the attorney-client privilege or work-product doctrine in SEC enforcement actions, does not occur with the level of frequency that one might otherwise envision based solely on the tenor of the public discourse. ${ }^{222}$ This does not necessarily imply, however, that the concerns raised against the possible waiver of the attorney-client privilege or work-product doctrine are without merit. ${ }^{223}$ Nevertheless, this analysis of publicly available sources

a non-waiver agreement); Millennium Partners, Securities Act Release No. 8639, Exchange Act Release No. 52863, 2005 SEC LEXIS 3078, at *24-25 (Dec. 1, 2005) (production of privileged material within the scope of a confidentiality agreement); Pilgrim, Securities Act Release No. 8505, Exchange Act Release No. 50680, 2004 SEC LEXIS 2642, at *15-16 (Nov. 17, 2004) (waiver of any evidentiary privileges, subject to enumerated exceptions); Baxter, Securities Act Release No. 8506, Exchange Act Release No. 50681, 2004 SEC LEXIS 2643, at *14-15 (Nov. 17, 2004) (waiver of any evidentiary privileges, subject to enumerated exceptions); Pilgrim Baxter \& Assocs., Advisors Act Release No. 2251, Investment Company Act Release No. 26470, 2004 SEC LEXIS 1267, at *21-22 (Jun. 21, 2004) (prospective waiver of any evidentiary privileges, upon written request by SEC staff); SEC v. Giesecke, Litigation Release No. 17745, 2002 SEC LEXIS 2423, at *8-9 (Sept. 25, 2002) (declining to assert any applicable privileges and sharing the results of an internal investigation); Rite Aid Corp., Exchange Act Release No. 46099, 2002 SEC LEXIS 1595, at *4 (Jun. 21, 2002) (declining to assert the attorney-client privilege and voluntarily providing full access to an internal investigation).

222. See Seigel, supra note 137, at 5 n.30.

223. On the contrary, the concern over a possible expansion of the practice of compelling the 
does provide support to the inference that, at least for the time period reviewed, the waiver of the attorney-client privilege or work-product doctrine occurred only infrequently. ${ }^{224}$

This inference, however, is necessarily limited to an assessment of SEC enforcement actions ${ }^{225}$ and may not extend to actions taken by the DOJ during the relevant time period. Recent scholarship by Professor Leonard Orland suggests that federal prosecutors may have been "overly aggressive" in that nearly eighty percent of deferred prosecution agreements prior to 2006 contained a waiver of the privilege. ${ }^{226}$ Although it is not completely clear how much, if at all, the customary practices of the SEC and DOJ may have diverged over the past decade in respect of waiver requests, additional analysis of SEC enforcement actions during the relevant timeframe reveals that settlement figures have substantially increased in aggregate amount. ${ }^{227}$ These statistical results, therefore, offer a more nuanced picture of the enforcement of federal securities law and the waiver issue, which may suggest that the contrary opinions - that there is indeed a "culture of waiver" or not-may be the

waiver of privilege can fairly be noted as precisely the issue of debate.

224. Indeed, based solely on these figures, one could make the claim that the waiver of the attorney-client privilege or work-product doctrine was an immaterial issue in SEC enforcement during the relevant time period. This said, such a claim would be subject to the rejoinder that while such a statistical analysis may provide some indication in respect of quantitative materiality, there remains an open question as to the qualitative materiality of the waiver issue. It is my belief that, given the substantial attention given to the waiver issue in both practice and scholarship, the issue warrants, at a minimum, further inquiry.

225. See supra notes 217-18 and accompanying text.

226. See Leonard Orland, The Transformation of Corporate Criminal Law, 1 BROOK. J. CORP. FIN. \& COM. L. 45, 78-80 (2006). "Th[e] empirical data reinforces the conclusion of the American Corporate Counsel Association that it is 'the regular practice of U.S. Attorneys to require corporations to waive their attorney-client privileges and divulge confidential conversations and documents in order to prove cooperation with prosecutors' investigations.”' Id. at 79-80 (quoting Wray \& Hur, supra note 205, at 1104-05); but see Mary Beth Buchanan, Effective Cooperation by Business Organizations and the Impact of Privilege Waivers, 39 WAKE FOREST L. REV. 587, 598 (2004) (survey conducted in 2002 of U.S. Attorneys "revealed that requests for waiver of the attorney-client privilege or work product protection were the exception rather than the rule: Waivers were requested in a very small number of cases ....”). Note, however, that Professor Orland's analysis focuses on non-prosecution and deferred prosecution agreements from 1993 to 2006, which number forty-four in the aggregate and thus constitute a different sample than is the case with the statistical analysis set forth herein, which comprises 1,472 data points. See supra notes 217-18 and accompanying text. Accordingly, the difference between the eighty percent cited by Professor Orland and the $0.61 \%$ set forth above should not be taken as an apples-to-apples comparison.

227. See Elaine Buckberg, Baruch LeV \& JAn LARsen, NERA Economic Consulting, SEC SETTLEMENTS: A NEW ERA POST-SOX 1 (2008) ("In recent years the [SEC] ... has imposed unprecedented penalties in enforcement actions.... Our research has shown that since [the Sarbanes-Oxley Act], the SEC has imposed penalties of \$10 million or more against 115 parties, including 14 that were penalized at least \$100 million.”), http://www.nera.com/nera-files/PUB_ New_Era_Post_SOX_1108.pdf. 
by-product of a more fundamental difference of perception as to the relevant issues under applicable privilege doctrine. If this is in fact the case, then it would appear that a reformulation of the question, rather than an extended debate on the possible answer, may yield more promising results.

\section{RETURNING TO THE FIRST PRINCIPLES OF UPJOHN CO. V. UNITED STATES}

It appears that the critical question in determining, and hopefully to some extent resolving, the issue of waiver of the attorney-client privilege and work-product doctrine in the enforcement of federal securities law relates to the appropriate boundaries of the corporate attorney-client privilege. ${ }^{228}$ Without a workable answer to this foundational question, any subsequent debate on the waiver issue will yield limited results. ${ }^{229}$ But in what manner should this important question be addressed? As noted previously, much of the debate in practice and scholarship has focused on the specific exceptions to waiver rather than the more general rule-namely, the possibility of selective waiver of materials generated as a result of an internal corporate investigation ${ }^{230}$ —or the SEC and DOJ policies in respect of such waiver as part of assessing the cooperation of a given corporation that may be under federal investigation. ${ }^{231}$

Rather than continue to debate the costs and benefits of selective waiver and the policies of the SEC and DOJ in relation thereto, I argue that the question should turn not on the exceptions to waiver, but on the first principles in doctrine that define the object in question-namely, the corporate attorney-client privilege. ${ }^{232}$ Accordingly, the discussion below focuses on these first principles in an effort to determine whether they more clearly frame the debate. When assessing these first principles, one

228. See supra Part II.B.1. Such a question, one might argue, follows from the more general inquiry as to the extent to which the modern corporations should enjoy the rights and privileges customarily reserved for natural persons. See supra notes 71-72 and accompanying text. While future articles will explore such matters in greater detail, for present purposes, the question of the appropriate boundaries of the corporate attorney-client privilege is the focus of inquiry.

229. As an elaboration, this is likely so because the discussion would then become one of opposing viewpoints as to the nature and purpose of the corporate form in and of itself. See supra note 70 . While such a discussion is of great importance to any understanding of law and its consequences, this Article, hopefully, provides some method by which one can settle upon a criterion that, while perhaps not perfect, at least improves the current doctrinal debate.

230. See supra Part II.C.

231. See supra Part III.B.

232. See supra Part II.B. 
must return to the reasoning of the Court in Upjohn Co. v. United States and, more specifically, its fundamental distinction between facts, on the one hand, and communication, on the other. ${ }^{233}$

\section{A. The Facts-Communication Model}

With respect to the attorney-client privilege, the distinction between facts and communication is one of primary importance. Indeed, the Restatement (Third) of the Law Governing Lawyers clearly makes this distinction by providing that the attorney-client privilege extends only to “(1) a communication (2) made between privileged persons (3) in confidence (4) for the purpose of obtaining or providing legal assistance for the client." ${ }^{234}$ Further, a "communication" is "any expression through which a privileged person... undertakes to convey information to another privileged person and any document or other record revealing such an expression." 235 In considering these definitions, one arrives at the conclusion that an expression constitutes a category of human behavior that can be viewed as separate and distinct from a fact or, to more fully state this line of reasoning, any knowledge of facts. ${ }^{236}$ Indeed, the Restatement (Third) plainly provides that "[t]he attorney-client privilege protects only the content of the communication between privileged persons, not the knowledge of privileged persons about the facts themselves." 237 So far, much of this discussion would appear to be non-controversial and rather self-evident. But can one draw a more general model from the facts-communication distinction with the purpose of addressing the question as to the appropriate boundaries of the corporate attorney-client privilege?

A review of the relevant literature of practitioners and scholars alike suggests that, at least among those in the field, the primary purpose for seeking a waiver of the corporate attorney-client privilege in a specific

233. See supra note 37.

234. REstatement (THiRD) OF THE LAW GOVERning LAWYERS § 68 (2000) (emphasis added).

235. Id. $\S 69$ (emphasis added). For additional discussion of the definition of a privileged person, see supra note 149 .

236. On the matter of knowledge of facts and its resulting implications on the corporate attorney-client privilege, the reasoning of the court in City of Philadelphia v. Westinghouse Elec. Corp., 205 F. Supp. 830 (E.D. Pa. 1962), provides the most compelling account in the case law. See supra Part II.B.2.a.

237. RESTATEMENT (THiRD) $\S 69 \mathrm{cmt}$. $\mathrm{d}$ (emphasis added). In further explicating this point, the Restatement (Third) notes that "[t]he client ... may invoke the privilege with respect to the question 'Did you tell your lawyer the light was red?' but not with respect to the question 'Did you see that the light was red?’” Id. 
case is to ascertain the relevant facts as part of the investigatory process. Indeed, former Deputy Attorney General James Comey noted in 2003, "[p]rosecutors are not generally seeking legal advice or opinion work product; they are just seeking the facts, including factual attorney work product.”238 Although this particular statement included the possibility of waiver of factual attorney work product, it would appear that the DOJ position has evolved to the point where, in congressional testimony in 2008, then-Deputy Attorney General Mark Filip stated:

Cooperation will be measured by the extent to which a corporation discloses relevant facts and evidence, not its waiver of privileges. The government's key measure of cooperation will be the same for a corporation as for an individual: to what extent has the corporation timely disclosed the relevant facts about the misconduct? That will be the operative question-not whether the corporation waived attorneyclient privilege or work product protection in making its disclosures. ${ }^{239}$

Accordingly, there appears to be an acknowledgement that the proper focus should be on the gathering of facts as part of the investigatory process, rather than a more exclusive fixation on the waiver issue. Such developments in DOJ policy appear encouraging since they highlight the importance of obtaining the facts and, therefore, that the possibility of waiver is merely one means to such an end. ${ }^{240}$

238. Richman, supra note 137, at 300 (emphasis added) (quoting Interview with U.S. Attorney James B. Comey Regarding Department of Justice's Policy on Requesting Corporations under Criminal Investigation to Waive Attorney Client Privilege and Work Product Protection, U.S. ATTORNEYs' Bull., Nov. 2003, at 1, http://www.justice.gov/usao/eousa/foia_reading_room/usab 5106.pdf); see also Buchanan, supra note 226, at 596 ("[T]he information disclosed pursuant to waiver is nearly always attorney work product concerning the underlying facts, rather than privileged communications.”). On this point, former U.S. Attorney Buchanan's argument with respect to the waiver of the work product doctrine is revealing-if the purpose is to obtain the underlying facts as the Court defined in Upjohn, see supra text accompanying note 100, then perhaps a more feasible alternative is to return to the first principles of Upjohn as opposed to entering into the doctrinal thicket of the waiver issue.

239. O’Sullivan, supra note 137, at 1274 (emphasis omitted) (quoting Letter from Mark Filip, Deputy Attorney Gen., to Patrick Leahy, Senator, U.S. Cong. (July 9, 2008)).

240. The primary importance of facts as part of the investigatory process is aptly explained in the following exchange in Christopher Nolan's film Memento, where the protagonist, Leonard, suffers from short-term memory loss and thus cannot form new memories. His counterpart in this scene, Teddy, is a recurring character in the film:

Leonard: I go on facts, not recommendations, but thank you.

Teddy: Lenny, you can't trust a man's life to your little notes and pictures.

Leonard: Why not?

Teddy: Because your notes could be unreliable.

Leonard: Memory's unreliable. 
Nevertheless, there remains the concern of how one can distinguish between facts and communication in the close case. This problem may be best illustrated in a simple Venn diagram, as set forth in Figure 2.

Figure 2: The Facts-Communication Distinction

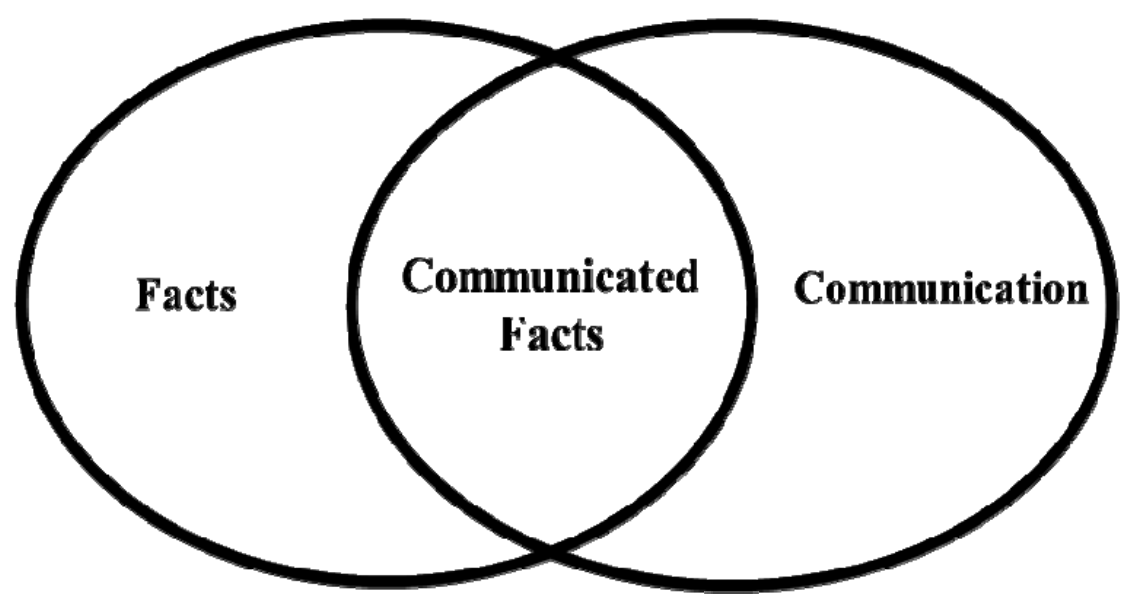

In many cases, non-privileged facts-or underlying facts in the phraseology of Upjohn ${ }^{241}$ — will be easily identifiable. For instance, if the chief executive officer of a given corporation has knowledge of securities fraud that occurred within the corporate enterprise, she cannot shield herself from a question in deposition as to her knowledge of this fact. $^{242}$ If this same chief executive officer communicated this knowledge to her counsel, however, then the SEC or DOJ attorney could

Teddy: [interjecting] Oh please.

Leonard: No, no, no, really. Memory's not perfect; it's not even that good. Ask the police. Eyewitness testimony is unreliable. The cops don't catch a killer by sitting around remembering stuff. They collect facts, they make notes, and they draw conclusions.

Teddy: [interjecting] That's not what I'm .... .

Leonard: Facts, not memories-that's how you investigate. I know, it's what I used to do. Look, memory can change the shape of a room. It can change the color of a car. And memories can be distorted. They're just an interpretation; they're not a record, and they're irrelevant if you have the facts.

Memento (Newmarket Capital Group 2000).

241. Upjohn Co. v. United States, 449 U.S. 383, 395 (1981).

242. See supra note 237. 
not question the chief executive officer or such counsel with respect to such communication without raising an issue of waiver of the attorneyclient privilege. ${ }^{243}$ What then of the case where the SEC or DOJ attorney seeks to discover certain facts that constitute communicated facts that may not be otherwise obtainable in the investigatory process or can only be ascertained at great expense? Supposing the communicated facts concerned those facts obtained as part of an internal investigation that spanned numerous foreign jurisdictions, is a purported claim for efficiency in the enforcement of federal securities law a sufficient argument in favor of waiver? ${ }^{244}$

Such an argument, standing by itself, cannot make the case for whittling away the attorney-client privilege. ${ }^{245}$ The reason why this must be, or at least should be, so are two-fold: first, obtaining factual work product in certain cases is already subject to a showing of substantial need and undue hardship as enunciated in Hickman v. Taylor and as mandated in Rule 26(b)(3) of the Federal Rules of Civil Procedure; ${ }^{246}$ and second, if indeed the corporate attorney is a gatekeeper for the corporate enterprise, ${ }^{247}$ she must be provided with the necessary tools and resulting methods by which she can, at least to some degree, provide a check on the otherwise uncontrolled impulses of would-be violators of the federal securities law.

In response, one might argue that the required showing of substantial need and undue hardship under Rule 26(b)(3) is too onerous and thus cannot work as a practical matter. Although this may be true to an extent, this does not necessarily mean that it would be impossible for the SEC and DOJ to obtain, for example, factual work product under the requirements of Rule 26(b)(3). ${ }^{248}$ All this would mean is that the SEC and DOJ would have to satisfy the procedural requirements that would

243. See supra note 237.

244. This was precisely the case in Upjohn where the general counsel or outside counsel interviewed eighty-six present and past employees. See Upjohn, 449 U.S. at 387, 395 n.3.

245. As a clarification, this is not because of any disagreement with respect to the importance of efficiency as part of a broader discussion of legal theory. Rather, the question is whether in this particular case the notion of prosecutorial convenience, which may or may not be necessarily efficient, should be the desired end.

246. See FED. R. CIV. P. 26(b)(3); supra note 130.

247. See Standards of Professional Conduct for Attorneys Appearing and Practicing Before the Commission in the Representation of an Issuer, 17 C.F.R. § 205.3 (2011); supra Part III.A.

248. See, e.g., In re Vitamins Antitrust Litig., 211 F.R.D. 1, 2, $5-7$ (D.D.C. 2002) (finding that factual work product generated in connection with Rule 30(b)(6) witness statements satisfies substantial-need and undue-hardship tests of Rule 26(b)(3) and is subject to in camera review). 
apply to any potential plaintiff against the corporation, which would be the case, for instance, in a class action involving federal securities law.

More importantly, however, is the notion that if we identify the corporate attorney as a gatekeeper - and thus accountable for any failure to address violations of federal securities law as a matter of legal ethics - then the gatekeeper must be empowered to carry out her appointed task. ${ }^{249}$ Perhaps it may be unfair to expect the corporate attorney to become the "conscience of the enterprise" as Professor Michael Seigel has observed, ${ }^{250}$ but once that decision has been madewhich, at least according to the Attorney Conduct Rules, is in fact the case $^{251}$ - then it becomes imperative to ensure that the requirements of legal ethics are matched by the safeguards of law. If, indeed, the corporate attorney as gatekeeper must now speak truth to power, then such a discussion must be protected by the attorney-client privilege in order to have its desired effect. An honest conversation that is not held in confidence will, one must imagine, not have much honesty at all.

\section{B. Comparison to Possible Alternatives}

The facts-communication model as presented above, while far from a perfect solution, hopefully has the benefit of simplifying the discussion to turn on one key determinant-whether the object in question is a nonprivileged or underlying fact or whether it constitutes a privileged communication between a client and counsel. ${ }^{252}$ The upshot of such an approach is that it has the potential to create a workable solution for both enforcement authorities and corporations.

In particular, the corporation will have a more identifiable means by which to establish its cooperation - that is, it may disclose the underlying facts without disclosing the privileged communication. Thus, the corporation may keep the final internal investigation report confidential, but it may also make available to the SEC or DOJ such corporate officers

249. See Regan, supra note 162, at 214 ("[T]he ethical issues involved in corporate representation often require us to address fundamental questions about the roles that lawyers play and the obligations to which they are held.”).

250. Seigel, supra note 137, at 45-46 ("In effect, lawyers do not want to be cast in the role of the conscience of the enterprise. And for good reason: no one likes being a killjoy. History demonstrates, however, that corporations are in desperate need of consciences, and who better to serve in this capacity than counsel?” (footnote omitted)).

251. 17 C.F.R. § 205.3.

252. See Upjohn Co. v. United States, 449 U.S. 383, 395-96 (1981) (noting the different protections given to facts and communications). 
and employees, together with such non-privileged materials that may provide the necessary background, so that the SEC or DOJ may "follow in the footsteps" of the internal corporate investigation. And if the focus should be on the facts in the investigatory process, could not this change in method allow for a result that satisfies the notable concerns raised while also following the dictates of Upjohn and its progeny?

One can imagine a number of possible alternatives to the question of the appropriate boundaries of the attorney-client privilege. ${ }^{253}$ In particular, Professor Lonnie Brown has recently proposed a fascinating solution to this issue by calling for a variation of the control-group test. $^{254}$ As Professor Brown explains, the control-group test can be refashioned along the lines of Comment 7 to Rule 4.2 of the ABA Model Rules of Professional Conduct. ${ }^{255}$ As a consequence, under such a modified control-group test, the corporate attorney-client privilege may then be limited to "only communications 'with those employees who exercise managerial responsibility in the matter, who are alleged to have committed the wrongful acts [that are] at issue ... or who have authority on behalf of the corporation to make decisions about the course of the [representation]., "256 As Professor Brown further explains, in following such an approach,

the proposed corporate attorney-client privilege will protect that about which corporations are primarily concerned-legal advice and incriminating statements attributable to the corporation-while leaving unprotected that which is reportedly of most interest to the government-factual information. The result is that corporations can be deemed "cooperative" by turning over the unprotected factual materials without the necessity of waiver and the related concerns that accompany it-i.e., subject matter waiver and waiver as to third parties. ${ }^{257}$

In this sense, therefore, Professor Brown's approach and the factscommunication model are quite similar in their intended goals. ${ }^{258}$

253. For instance, privileged communications could be subject to an in camera review in the given case. I thank Professor Hazard for providing this important insight.

254. Brown, supra note 137, at 951-57.

255. Id. at 952-53 (citing MOdel RULES OF PROF’L CONDUCT R. 4.2 cmt. 7 (2004)).

256. Id. at 953 (alterations in original) (quoting Messing, Rudavsky \& Weliky, P.C. v. President \& Fellows of Harvard Coll., 764 N.E.2d 825, 833 (Mass. 2002)).

257. Id. at 956 (footnotes omitted).

258. Indeed, the facts-communication model should be considered as being in concert with the sentiment expressed by Professor Brown that "[w]hen something appears to be dead or dying, the proper solution is not to merely proclaim that it is alive and well or behave as if band-aid type 
There does, however, appear to be a slight but significant difference in these two approaches, as illustrated in Figure 3 immediately below.

\section{Figure 3: Modified Control Group and Facts-Communication Models}

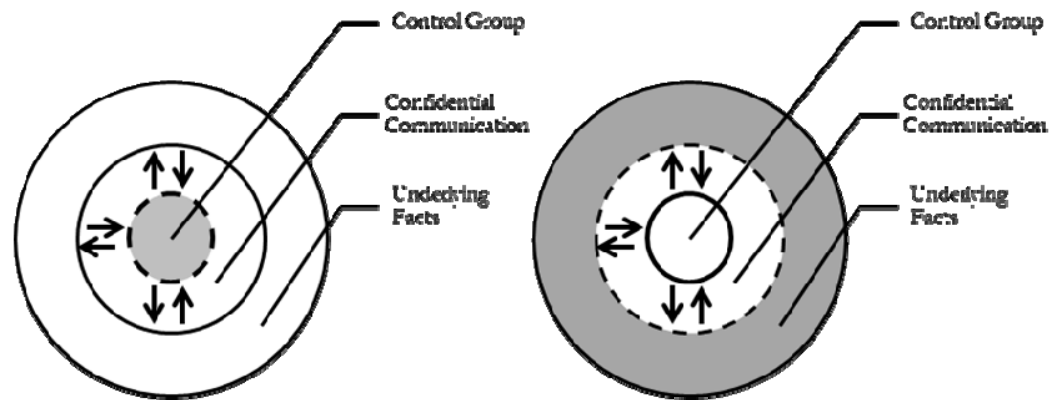

The diagram on the left presents the implications of Professor Brown's proposal and stands in contrast to the diagram on the right, which sets forth the facts-communication model. The key difference is the determination as to the precise ambit of the corporate attorney-client privilege. Under Professor Brown's proposal, the critical question is whether the specific agent of the corporation, or the "privileged person" in the terminology of the Restatement (Third) ${ }^{259}$ is an individual that will fall within the definition of the "control group" as informed by Comment 7 to Rule 4.2 of the ABA Model Rules of Professional Conduct. ${ }^{260}$ Thus, in the diagram on the left, the dotted line with corresponding arrows to indicate that the question of the limits of the control group is the critical issue under such a criterion.

In contrast, however, the diagram on the right indicates that the focus under the facts-communication model is not the control group, but on the fundamental distinction between an underlying fact and a privileged communication. ${ }^{261}$ Accordingly, the dotted line runs along the second of

remedies will do the trick. The only solution is to breath[e] new life into the declining vessel." Id. at 957. In this sense, Lord Brougham's opinion in Bolton and Greenough may be instructive in their effect-the attorney-client privilege is dead, long live the attorney-client privilege. See supra Part II.A.1-2.

259. See Restatement (THIRD) OF THE LAW GOVERNING LAWYERS § 70 (2000).

260. See supra notes 255-56 and accompanying text.

261. As to the possible distinction between fact and communication, for purposes of this Article such a distinction remains a first principle of privilege law. See supra note 37. 
the three circles - which is precisely the line drawn by the Court in Upjohn. ${ }^{262}$ And while the distinction between an underlying fact and a privileged communication may be far from clear in an individual caseand thus the corresponding arrows in the diagram on the right-the advantage of such an approach is that it does not require the Court to overturn Upjohn and move from the subject-matter test to the controlgroup test. ${ }^{263}$ The notable difference, therefore, is in the focal point as denoted in the shading in each of the diagrams-while Professor Brown focuses on the most sensitive information that rests within the control group, the facts-communication model widens the scope of vision to capture, as John Adams once called, those "stubborn things"- that is to say, the facts. ${ }^{264}$

\section{CONCLUSION}

The question of the appropriate boundaries of the corporate attorneyclient privilege is not a matter that is capable, or perhaps even suitable, of being resolved by a simple solution. If, in fact, there were such an elusive solution, one must imagine that the law would have already

262. Upjohn Co. v. United States, 449 U.S. 383, 395-96 (1981).

263. On this point, Professor Julie O'Sullivan notes the possible difficulties with an approach that would seek to move from the subject-matter test to the control-group test. See O'Sullivan, supra note 137, at 1265 ("Professor Brown's proposal is fairly new, but, given the high regard in which the bar holds Upjohn and, more important, the bar's reaction to one outstanding proposed 'solution' to the lack of a selective waiver doctrine-proposed Federal Rule of Evidence 502(c) - it is fair to assume that the bar will not be rushing to endorse this 'fix.'”).

264. In relation to the comparison of these different perspectives on law, I especially thank Professor Brown for his helpful comments on such points. A more specific discussion of the theoretical distinctions that may apply to the modified control group and facts-communication models, while beyond the scope of this Article, may offer additional insights into this important area of law. For instance, to what extent does the extension of the attorney-client privilege to persons without the control group - that is, in a manner consistent with the Court's holding in Upjohneffectively incentivize or disincentivize better corporate governance, broadly considered? On the one hand, one might argue that a broadly defined attorney-client privilege as delineated in Upjohn realizes the intention of the SEC's voluntary disclosure program in that corporations will be properly motivated to investigate themselves. See supra note 84 . Then again, might this not provide the corporation with the ability to unduly influence and thus in some manner silence would-be corporate whistleblowers, i.e., persons without the control group, in a manner that is inconsistent with certain policy objectives of corporate and securities law? See, e.g., Geoffrey Christopher Rapp, Beyond Protection: Invigorating Incentives for Sarbanes-Oxley Corporate and Securities Fraud Whistleblowers, 87 B.U. L. REV. 91 (2007). But should not the corporation be given at least the initial opportunity to resolve any possible violations of corporate and securities law given that it is the least cost avoider; thus, Upjohn can be viewed as reducing the transaction costs that will be incurred when conducting internal investigations. See, e.g., Ronald H. Coase, The Problem of Social Cost, 3 J.L. \& ECON. 1 (1960). While such questions are not specifically addressed in this Article, hopefully such inquiries within the scholarship may now be more intensely explored as a consequence of the discussion provided herein. 
arrived at such an endpoint. In the case of the possible waiver of the attorney-client privilege or work-product doctrine, however, there may be some utility in returning to the start. At the conclusion of the oral argument before the Court, counsel for Upjohn observed:

In closing, Your Honor, I would just like to say that I think Justice Stevens' questions about why the Internal Revenue Service didn't go after the people who were interviewed and who signed these questionnaires really discloses what the Internal Revenue Service is doing here. They're not interested in the facts, they either have them or they can get them. What they want is the lawyer's input. And that's what we're fighting about here. ${ }^{265}$

Although it is likely that the debate concerning the waiver issue will continue for a number of years to come, there is also the sense that the fundamental questions have already been asked and that the long arc of judicial opinions-beginning with Lord Brougham in Bolton and Greenough and ending with the Court in Upjohn-has provided a rather consistent response. The challenge, therefore, is to apply these judicial first principles in practice, which is an endeavor that-when cast in the light of the historical development of the privilege- has no end.

265. Transcript of Oral Argument, Upjohn, 449 U.S. 383 (No. 79-886), 1980 U.S. Trans. LEXIS 69 , at $* 51$ (emphasis added). 